\title{
DOMESTIC BANK REGULATION AND FINANCIAL CRISES: THEORY AND EMPIRICAL EVIDENCE FROM EAST ASIA
}

\author{
Robert Dekle \\ Kenneth M. Kletzer \\ Working Paper 8322 \\ http://www.nber.org/papers/w8322
NATIONAL BUREAU OF ECONOMIC RESEARCH
1050 Massachusetts Avenue
Cambridge, MA 02138
June 2001

We are grateful to Peter Clark, Vikram Haksar, Kalpana Kochhar, Kanitta Meesook, Reza Moghadam, Paulo Pesenti, Charles Calomoris, Sebastian Edwards, Jeffrey Frankel and other participants in the NBER conference, "Currency Crisis Prevention," in Islamorada, Florida, January 11-13, 2001, for many useful and insightful comments and suggestions. Kletzer is grateful to the Research Department of the International Monetary Fund for supporting his research on this paper. The views expressed herein are those of the authors and not necessarily those of the National Bureau of Economic Research or the IMF.

(C) 2001 by Robert Dekle and Kenneth M. Kletzer. All rights reserved. Short sections of text, not to exceed two paragraphs, may be quoted without explicit permission provided that full credit, including $\odot$ notice, is given to the source. 
Domestic Bank Regulation and Financial Crises:

Theory and Empirical Evidence from East Asia

Robert Dekle and Kenneth M. Kletzer

NBER Working Paper No. 8322

June 2001

JEL No. F31, F41

\begin{abstract}
$\underline{\text { ABSTRACT }}$
A model of the domestic financial intermediation of foreign capital inflows based on agency costs is developed for studying financial crises in emerging markets. In equilibrium for the model economy, the banking system becomes progressively more fragile under imperfect prudential regulation and public sector loan guarantees until a crisis occurs with an expected reversal of capital flows. The crisis in this model evolves endogenously as the banking system becomes increasingly vulnerable through the renegotiation of firm debts. Firm revenues are subject to idiosyncratic firm-specific technology shocks, but there are no aggregate shocks.

The model generates dynamic relationships between foreign capital inflows, domestic investment, firm debt and the value of firm and bank equity in an endogenous growth model. Prior to crisis, foreign capital inflows and bank debt rise relative to investment and domestic production. The aggregate portfolio of the banking sector deteriorates and the total value of bank equities declines in proportion to that for goods producers progressively. The model's assumptions and implications for the behavior of the economy before and after crisis are compared to the experience of five East Asian economies. The case studies compare three crisis or near-crisis countries, Korea, Thailand and Malaysia, to two non-crisis economies, Taiwan and Singapore, and lend support to the model.
\end{abstract}

Robert Dekle

Department of Economics

KAP 300, University Park Campus

University of Southern California

Los Angeles, CA 90089

dekle@usc.edu
Kenneth M. Kletzer

Social Sciences I

Department of Economics

University of California

Santa Cruz, CA 95064

and

International Monetary Fund

kkletzer@cats.ucsc.edu 


\section{Introduction}

The financial crises in East Asia followed several years of large foreign financial capital inflows intermediated by the domestic banking system. The crisis countries suffered tandem banking and currency crises that produced sharp reductions in economic growth and subsequent ongoing domestic financial distress. In some cases, it was clear beforehand that the domestic financial system was becoming increasingly fragile and crisis-prone, for example, in Thailand. The currency crisis made matters worse due to the uncovered foreign currency exposure of the banking system. A number of authors have also argued that implicit government guarantees of foreign currency liabilities of the domestic banks contributed to the financial crisis in Asia. More generally, Calvo [1998a] observes that emerging market financial crises evolve through complicated interactions between domestic financial sectors, international lenders and national monetary and fiscal authorities. Our paper considers the dynamic consequences of interactions between the microeconomics of private financial intermediation and public sector financial and macroeconomic policies in a currency crisis model. We focus on the relationship between foreign capital inflows, economic growth and subsequent banking crises under a fixed exchange rate. Most importantly, we relate the assumptions and implications of our model to the East Asian currency crisis. We use the theoretical framework as a basis for comparing the experience of five East Asian economies in the 1990s. This sample includes two economies that experienced currency crisis, Korea and Thailand, one that almost experienced crisis, Malaysia, and two economies that did not experience crisis, Taiwan Province of China and Singapore.

In an insightful paper, Carlos Diaz-Alejandro [1985] uses the Chilean financial crisis of 1981-1983 to illustrate the dangers of financial reforms under fixed exchange rates, free international capital flows, implicit guarantees of bank deposits, but weak domestic financial supervisory systems. The financial crisis in Chile followed several years of steady liberalization and privatization of domestic 
banking under explicit and repeated claims by the authorities that deposits would not be insured by the government. When tested in the late 1970s, the government intervened and rescued all depositors. As capital inflow restrictions were relaxed in 1981, capital inflows surged under the anticipation of public bailouts as the domestic financial sector continued to deteriorate until their sudden reversal in the currency crisis.

Diaz-Alejandro [1985] is impressively prescient of the East Asian crisis. In this paper, we propose a theoretical model that formalizes his interpretation by concentrating on the interactions between domestic financial institutions, the regulation and subsidization of domestic financial intermediation by the government and foreign capital inflows leading up to a financial crisis. The model generates a path for domestic bank lending, capital accumulation and the growth of the foreign currency debt of domestic banks that ultimately leads to a financial crisis with the collapse of the fixed exchange rate regime. The underlying disturbances in the model are simply idiosyncratic productivity shocks across firms when there are a large number of firms; there are no exogenous aggregate shocks. However, a problem of agency in domestic financial intermediation leads banks to accumulate increasingly risky assets in equilibrium until the financial system is vulnerable to collapse with a reversal of foreign capital flows. A key element of our model is that the government provides implicit guarantees of the foreign currency liabilities incurred by domestic banks following Diaz-Alejandro [1985] and recent "third-generation" models of currency crises.

The theoretical model introduces an agency model of banking in the spirit of Bernanke and Gertler [1989, 1990] and Bernanke, Gertler and Gilchrist [1999] in which domestic banks have an informational advantage in lending to domestic firms into a simple endogenous growth model. Adverse selection in the choice of risky projects by firms leads to the co-financing of investments by firm owners and banks. Individual firms become insolvent with positive probability in finite time, in which event banks have incentives to renegotiate the firm's debt in this model. With time, the proportion of firms that have been 
unable to repay their gross debt and renegotiated their loans in the past increases stochastically.

Foreign capital inflows allow lending and aggregate output to grow without being constrained by domestic savings. The implicit insurance provided foreign creditors in the event that the government abandons the fixed exchange rate sustains capital inflows to the banking system until the crisis occurs. Over time, the domestic financial sector becomes increasingly fragile in this model. Prior to the crisis, capital inflows rise in proportion to domestic production under constant returns to accumulable factors of production. Investment may or may not rise as a ratio of output. The model also predicts that the total equity value of the banking sector will be decreasing in absolute value and in proportion to the equity value of the borrowing firms. The banking system becomes progressively more indebted through foreign borrowing until it is ultimately insolvent. Capital inflows cease in a sudden stop, investment reverses and output drops sharply. The post-crisis rate of growth will depend upon the new incentives for foreign capital inflows after the crisis.

Other papers adopt the financial accelerator model of Bernanke and Gertler or its underlying agency model of financial intermediation for analyzing the link between foreign capital inflows and currency crises. Velasco [1987] introduces banking into a version of the Krugman [1979] model of speculative attacks on a fixed exchange rate regime, and Aghion, Bacchetta and Banerjee [1999a, 2000] study the amplification of aggregate shocks in credit-constrained economies. Our analysis is quite different in that we detail the microeconomics of intermediation and focus on the path-dependence of financial fragility in the open economy leading up to a crisis with only firm-specific idiosyncratic shocks. The role of the implicit government guarantees follows the observations made by Diaz-Alejandro [1985] and Calvo [1998a] that a sovereign government has an incentive to subsidize foreign capital inflows to overcome the problem of its own moral hazard in setting trade, fiscal and monetary policies. Mishkin [1996] and Obstfeld [1998] among others have observed that government guarantees of foreign currency deposits in the event of devaluation appear to be an implicit companion to a pegged exchange rate regime. The 
currency crisis in our model is generated by contingent public sector insurance in the same way as in the "third-generation" models proposed by Calvo [1998a and b] and Dooley [2000]. The emphasis on fragility of the banking sector bears much in common with description and analysis of the East Asian crisis by Corsetti, Pesenti and Roubini [1998a]. Other models that elaborate on the role of public sector guarantees of foreign currency debt and domestic banking include Burnside, Eichenbaum and Rebelo [1999] and Chinn and Kletzer [2000].

A number of theoretical and empirical papers have been written on the possible causes of the East Asian crisis and its consequences. These include fundamentals-based models, following Krugman [1979] and Flood and Garber [1984] such as this, and ones based on liquidity crises as exemplified by Chang and Velasco [1999]. ${ }^{1}$ An alternative approach for modelling domestic intermediation would be to adopt a model in which collateral plays a central role for enforcing repayment. Caballero and Krishnamurthy [1998] and Edison, Luangarum and Miller [2000] both adopt the Kiyotaki and Moore [1997] model of credit cycles to study financial crises in emerging markets. The Kiyotaki and Moore model precludes the renegotiation of bank loans, although it can portray the collapse of the value of fixed assets and bank insolvencies during a systemic crisis. Christiano, Gest and Roldos [2000] develop a different version of the Kiyotaki and Moore model in a financial crisis model that endogenizes asset values more richly. Although collateral does not enter contract enforcement in our model of financial intermediation, the model could be extended to endogenize the value of physical assets.

Section 2 presents the theoretical model and its empirical implications. Sections 3 and 4 compare the assumptions of the model and its the predictions to the data for the five Asian economies in our sample with broad success. We first discuss how each, Korea, Thailand, Malaysia, Taiwan Province of China, and Singapore, differs with respect to the institutional characteristics of banking and corporate borrowing underlying our assumptions. We argue that the necessary assumptions for the endogenous banking and currency crisis to arise in the theoretical model fit Korea and Thailand, the crisis cases, 
very well and Malaysia reasonably well, but do not fit the cases of Taiwan Province of China and Singapore. Section 4 shows that how the paths for aggregate measures of economic and banking system performance differ across the economies in a manner predicted by the model.

\section{A Theoretical Model of Financial Crises}

We model international capital flows and domestic financial intermediation in an infinitely-lived small open economy with capital accumulation in discrete time. Firms are established by entrepreneurs each of whom has access to a set of projects that can be undertaken. Investment by firms is financed by domestic household savings or by foreign financial capital inflows. These financial flows are intermediated by banks. In our model, banks operate a monitoring technology, and some of the potential entrepreneurs have access to this technology.

The economic environment is described first and followed by an analysis of the dynamics of bank lending. The role of foreign capital inflows and the dynamics of a financial crisis are then discussed.

\subsection{Economic Environment}

There is a single good that can be consumed, invested or traded internationally. It can be produced using entrepreneurial labor and capital. The model allows investment to be reversible, although we will consider the consequences of costly dismantling of a firm's capital stock. For simplicity, there is no depreciation. Production takes one period, and the gross output produced in any period is stochastic.

All residents have identical preferences over infinite-horizon consumption plans and are endowed with a single unit of labor each period. Each person is a potential entrepreneur who can select and invest in a new project every period. The investment opportunities available to different people do not need to be identical, so that entrepreneurs may be heterogeneous with respect to skills or knowledge. However, the set of techniques of production available to each entrepreneur does not change over time, and a subset of entrepreneurs know how to operate banks. 
Households are risk averse and seek to smooth consumption over time. They receive entrepreneurial income and interest earnings from financial savings. The utility function for a household is given by

$$
U_{t}=E_{t} \sum_{s=t}^{\infty} \beta^{s-t} u\left(c_{s}\right),
$$

where $u(c)$ is strictly concave and $0<\beta<1$. This is maximized with respect to a consumption plan subject to the intertemporal budget identity,

$$
a_{s+1}-a_{s}=\left(r_{s}^{d} w_{s}+r^{*} f_{s}\right)+\pi_{s}-c_{s}-\varphi\left(w_{s}\right)
$$

and the solvency condition,

$$
\lim _{s \rightarrow \infty} a_{s} \prod_{v=t}^{s-1}\left(\frac{1}{1+r_{v}^{*}}\right) \geq 0,
$$

given initial financial wealth, $a_{t}=w_{t}+f_{t}$. Here, $w$ equals deposits held in domestic banks which earn a deposit rate of interest, $r^{d}$, and $f$ equals holdings of foreign deposits which earn interest, $r^{*}$. Domestic transactions are denominated in units of domestic currency, and the nominal exchange rate is fixed. Money is held (in the form of interest-bearing deposits) to economize on transactions costs, $\varphi\left(w_{t}\right)$, where $\varphi^{\prime}\left(w_{t}\right)<0$. If domestic residents hold foreign assets in equilibrium, then the opportunity return to domestic bank deposits, $r^{d}-\varphi^{\prime}\left(w_{t}\right)$, will be equal to the foreign currency rate of interest, $r^{*}$, less any currency risk premium. If foreign residents hold domestic deposits (as we will assume they do in equilibrium), then $r^{d}$ will equal $r^{*}$ corrected for currency risk and all domestic financial savings will be held in domestic banks. $\pi$ represents entrepreneurial income from production. The model has been written under the assumption that each entrepreneur owns the equity in her firm. Tradable equity complicates the presentation without much gain, but we will be interested in the value of firm equity later. The inclusion of a demand for money is used to justify invoking a conventional monetary model of the nominal exchange rate later. ${ }^{2}$ Demand deposits pay a positive rate of return so that money is held only as deposits in equilibrium for the model economy.

Each firm is established by a particular entrepreneur. Production uses capital and one unit of 
entrepreneurial labor to produce output each period. Production displays constant returns to capital and increasing returns to entrepreneurial effort. The quantity of output produced by any given input bundle is stochastic. Each entrepreneur has access to a particular collection of possible projects she can undertake. Projects differ with respect to the distribution of output produced across states of nature for any given capital input. For example, the distribution of output for one project might be a mean-preserving spread of another. The set of projects available to each non-bank entrepreneur can either be the same or different. In either case, entrepreneurs can choose to undertake different projects.

The production function for a firm $j$ is given by

$$
y_{t}^{j}=\alpha_{t}^{j} k_{t}^{j},
$$

where $k_{t}^{j}$ is the capital stock of firm $j$ predetermined by investment undertaken in period $t-1 . y_{t}^{j}$ is output gross of the capital stock, so that $\alpha_{t}^{j}$ is the stochastic (marginal and average) gross productivity of capital. For each possible project, $\alpha_{t}^{j}$ is non-negative and distributed identically and independently across time. A project is uniquely determined by its distribution over the productivity of capital.

Firms can finance capital accumulation by borrowing from banks or by investing their own savings. Each entrepreneur will seek to diversify her income risk by allocating her wealth between bank deposits and equity in her own firm. Her choices are limited to these two by imperfect information. Bankers have an absolute advantage at monitoring firm choices of projects and realized output each period. Households reduce their exposure to risk by lending to banks which in turn lend to many firms, thereby diversifying individual firm project risk for their depositors. Firms can use current profits to finance investment (retained earnings) or pay dividends to the owner-household. To make the connection to corporate borrowing from this model of entrepreneurship, we add the restriction that the household cannot be forced to draw against its other assets (bank deposits) to supply additional capital to the firm it owns. That is, we separate the entrepreneurial role of the owner from the savings and consumption role of the household in Robinson Crusoe fashion. 
The well-known model of banking as delegated monitoring (Diamond [1984], Freixas and Rochet [1997]) works to rule out direct equity investment by households in the projects of other entrepreneurs and implies that banks use conventional debt contracts. The model assumes that output realizations by a firm in any period are costlessly observed only by the entrepreneur of that firm and that bankers have access to a technology that allows them to observe project outcomes at a lower cost than households. To make things simple, assume that households are unable to observe the actual output of any firm other than their own at any cost; below we discuss weakening this assumption and allowing equity trade. We also assume that the costs of monitoring a firm are indivisible, so that economies of scale are realized when firms borrow from a single bank in equilibrium. ${ }^{3}$

While costly observability can be used to rationalize bank lending via standard debt contracts, the primary informational asymmetry here concerns the choice of project by the firm. This choice involves adverse selection as in a variety of credit market models following Stiglitz and Weiss [1981]. The bank lends an amount $\ell_{t}$ to a typical firm in period $t-1$ to finance a capital stock equal to $k_{t}$ which will produce output in period $t$. The firm selects its project for period $t$ in period $t-1$ to maximize its value. The firm's capital stock evolves according to

$$
k_{t+1}=\alpha k_{t}-R_{t} \ell_{t}+\ell_{t+1}-\pi_{t}
$$

where $R_{t}$ is the gross interest charged to the period $t$ loan. Consider the simple case a single round of lending with no ongoing capital accumulation and production. In this case the return to the firm under limited liability is given by

$$
\text { firm's return }=\max \left\{\alpha_{t} k_{t}-R_{t} \ell_{t}, 0\right\}
$$

whereas the return to the bank is given by

$$
\text { bank's return }=\min \left\{R_{t} \ell_{t}, \alpha_{t} k_{t}-\gamma\right\}-\left(1+r_{t}^{d}\right) \ell_{t},
$$

where $\gamma$ represents observation costs. The borrower will choose a riskier project from among those with 
a common mean than is in the best interests of the lender. While informational imperfections restrict an entrepreneur's capacity to diversify her income risk, limited liability and the conventional debt contract provide a degree of risk sharing between households that is constrained by the disincentives for borrower risk avoidance.

Co-financing given by the difference, $x_{t}=k_{t}-\ell_{t}$, reduces the incentives for the firm to choose a riskier project and raises the expected return to the lender. This is immediately true for the repeated lending case in our capital accumulation model. The bank chooses a combination of loan size, $\ell_{t}$, rate of interest, $r_{t}=R_{t}-1$, and co-financing requirement,

$$
z_{t}=\frac{k_{t}-\ell_{t}}{k_{t}}
$$

to maximize its expected return. This is demonstrated by Bernanke and Gertler [1989 and 1990] in a moral hazard model. They explain the importance of co-financing as a solution to the agency problem in banking and for generating financial fragility. Another way to motivate bank lending in our model is to assume that banks have a cost advantage setting $z_{t}$ by monitoring the investment level of the firm.

Limited liability plays a key role in this economy. Firms can go bankrupt, which means here that current assets, $\alpha_{t} k_{t}$, accrue to the bank, and the firm ceases to exist. A firm would only choose bankruptcy if its value as an ongoing enterprise was non-positive. When the firm cannot service its debts in full, the bank faces a choice of declaring the firm bankrupt or renegotiating the terms of its loan. Equivalently, a bank can go bankrupt if it cannot meet its deposit liabilities as demanded by depositors. With reversible investment, all the assets of the client firms of a bank can be used to meet depositors' claims so that a bank will only be unable to repay its deposit liabilities on demand if the sum of the capital stocks of each of its client firms fails to exceed the gross interest it has promised depositors. When investment is non-reversible, at least in the short run, then the bank can be illiquid without being insolvent. The production function could be rewritten to incorporate time-to-build to allow for the possibility of self-fulfilling bank runs as demonstrated by Diamond and Dybvig [1983] and used in the 
Chang and Velasco [1999] model of financial crises. This extension is not explored in this paper. The renegotiation of bank loans, option value of the firm and the role of deposit insurance are discussed in the next subsection.

The economy will be open to international financial capital inflows and outflows. Net capital inflows are equal to the current account deficit plus any increase in central bank reserves through the balance of payments identity. Private foreign borrowing is intermediated by domestic banks. The current account surplus is given by

$$
b_{t+1}-b_{t}=r_{t}^{*} b_{t}+\left(y_{t}-\varphi\left(w_{t}\right)\right)-c_{t}-k_{t+1}
$$

where $b_{t}$ is the current stock of foreign debt for the country denominated in units of foreign currency and other variables are expressed as economy-wide aggregates. Since quantities are expressed in nominal terms, we assume that nominal prices are perfectly flexible and that purchasing power parity and uncovered interest parity hold. All debt in the model is short-term debt.

Fiscal policy plays a key role for generating a currency crisis under the fixed exchange rate regime. There are no public expenditures but the government can provide deposit insurance for domestic residents and debt repayment guarantees to foreign lenders. These contingent liabilities could be financed through taxes (including premia charged to banks or depositors) or through monetization. For simplicity, deposit guarantees will be financed by current or future monetization in the model.

\subsection{Capital Accumulation and Bank Lending}

In this section, we consider the dynamics of domestic bank lending and economic growth in the closed economy. The capital account will be opened later. The economy starts in a state in which all firms have the same capital stock and, for expositional simplicity, we let all projects be chosen from a common set

First, consider the case of a firm that realizes a high output in period $t$. The net income for the firm 
is given by

$$
(\alpha-1) k_{t}-r_{t} \ell_{t}>0
$$

so that the entrepreneur can consume a dividend or increase her equity in the firm $(r \equiv R-1)$. This firm's bank made its loan offer in period $t-1, \ell_{t}$, optimally given the collection of projects available and the entrepreneur's contribution to the firm's investment. In general, the equilibrium loan will lead to a positive value of $z$ less than one. ${ }^{4}$ The banker then is willing to lend an additional amount,

$$
\ell_{t+1}-\ell_{t}=\frac{1}{z}\left[(\alpha-1) k_{t}-r_{t} \ell_{t}\right]
$$

leading to an increase in the firm's capital stock of

$$
k_{t+1}-k_{t}=\frac{1+z}{z}\left[(\alpha-1) k_{t}-r_{t} \ell_{t}\right]
$$

if the interest rate $r_{t}^{d}$ remains unchanged. This equation of motion incorporates the financial accelerator that plays a central role in Bernanke and Gertler [1989 and 1990]. Furthermore, this firm is able to repay its entire debt at time $t$. Therefore, it could pay off its debt to its current bank and take a new loan (of size $\ell_{t+1}$ above) from another bank. That is, it can rollover its short-term debt on the market. Competition among banks ensures that the interest rate charged on the loan, $\ell_{t+1}$, is independent of the rest of the bank's particular portfolio. ${ }^{5}$

Instead, suppose that the firm realizes a low level of output. In this case, we have

$$
(\alpha-1) k_{t}-r_{t} \ell_{t}<0
$$

but either

$$
\alpha k_{t}-R_{t} \ell_{t} \geq 0 \quad \text { or } \quad \alpha k_{t}-R_{t} \ell_{t}<0
$$

In the first instance, the firm contracts according to equation (11). In the second, the firm is unable to meet its debt obligations even if it liquidates its entire stock of capital. In this case, the firm can be declared bankrupt by its creditor. However, the bank can possibly do better than to liquidate the firm and use the proceeds to repay its depositors or pay its owner dividends. This is because the bank now 
has market power vis-a-vis the firm in a debt rollover or renegotiation under a simple seniority rule. Another bank possibly could offer a new loan to the firm allowing it to pay off its debt and invest for the next period. Under such a loan, investment is given by

$$
k_{t+1}-\ell_{t+1}=\alpha k_{t}-R_{t} \ell_{t}<0 .
$$

That is, the firm's investment is less than the loan principal. The new bank must charge an interest premium to recover the opportunity cost of the portion of the loan used by the firm to pay off its period $t$ debt. This kind of loan may not even be offered because the entrepreneur now owns none of the capital stock of the firm ( $z$ is zero) which along with the higher interest rate encourages greater risk taking by the entrepreneur.

The current bank, however, may gain by offering a new loan when other lenders will not. This is the case if

$$
\max _{R, \ell} E_{t}\left[\min \{R \ell, \alpha \ell-\gamma\}-\left(1+r_{t+1}^{d}\right) \ell\right]>0
$$

given the optimal choice of project by the borrower conditional on $R$ and $\ell$. The implied interest rate premium is constrained by the premium that a new lender would charge. When such a premium does not exist, as a consequence of the agency problem, the firm's current banker faces no potential competition in the rollover market. The excess returns on such a new loan are applied against the opportunity cost of the unpaid period $t$ debt, $R_{t} \ell_{t}$. Therefore, the firm's bank can choose to rollover the unpaid debt and offer new capital in exchange for a deeper claim, $R_{t+1}\left(\ell_{t}+k_{t+1}\right)$, against the earnings of the firm, $\alpha k_{t+1}$, in favorable states of nature. The supernormal profits on these rollovers encourage the renegotiation of short-term bank debt and discourage the formal bankruptcy of insolvent firms when inequalities (14) and (15) hold. For inequality (15) to hold, we need to impose the condition that the optimal project choice of the entrepreneur when $z=0$ yields at least positive expected total surplus; that is, $E_{t} \alpha>1+r_{t}^{d}$. The level of new capital provided to the firm is chosen by the banker along with the interest rate to maximize her utility from the profits she realizes on her entire portfolio. These 
incentives will rise if liquidating a debtor is costly for banks.

We note that the equilibrium loan renegotiation can simply be written as a rollover of the unpaid gross interest at the new rate of interest. Write-downs are unnecessary, since any unpaid gross interest in the future can continue to be rolled over in renegotiations. Through repeated loan rollovers, the bank may acquire a permanent monopoly franchise on lending the firm, but it will only enforce repayment terms in equilibrium that maximize the banker's expected utility from her portfolio. ${ }^{6}$

The projects undertaken by insolvent firms in a rollover will be riskier than those the same firm chose when its net worth was positive. Suppose that the set of projects includes a continuum of mean-preserving spreads of the project chosen by the firm at the initial equilibrium co-financing requirement, $z$. When the firm becomes insolvent (inequality 14 holds) and the loan is renegotiated, the entrepreneur to choose a mean-preserving spread of the original project because $z$ is zero. The interest premium provides an additional reason for the debtor to make a riskier choice of project. The probability that the bank's borrowing cost of the new capital, $\left(1+r_{t+1}^{d}\right) k_{t+1}$, exceeds the gross project returns, $\alpha k_{t+1}$, is greater for the renegotiated loans of insolvent firms than for loans to solvent firms.

Once a bank has rolled over the debt of one of its clients, it faces a higher probability of loan rollovers for this firm in the future. The probability that the firm will need to renegotiate it debts again,

$$
\operatorname{Pr}\left\{\alpha k_{t} \leq R_{t} \ell_{t}\right\}
$$

rises with $\ell_{t}-k_{t}$. Further, for the new capital provided to the firm, the probability that its cost to the bank will not be covered,

$$
\operatorname{Pr}\left\{\alpha k_{t} \leq\left(1+r_{t}^{d}\right) k_{t}\right\}
$$

rises as the project choice becomes riskier. These rollovers are negotiated in a forward-looking fashion, but their probability and terms are path-dependent. Renegotiating bank debt through rollovers and providing new capital is superior for the bank to cutting its losses. While the bank is rolling over loans, it must also be rolling over deposit liabilities. A firm's debt will continue to be rolled over in equilibrium 
as low output states of nature are realized until the claim of the bank exhausts all the possible payments that it can extract from the firm in every future event. This occurs with positive probability and means that the opportunity cost (deposit liability incurred) of the ultimate loan exceeds its expected return.

Banks face competition from each other for loans to firms that have been able to repay their debts in full in the previous period (for example, growing firms). The interest premium charged on loans to these customers covers the expected present value loss if revenues fall short of the opportunity cost of the funds lent. This present value is calculated taken into account the equilibrium renegotiation of loans that fall into default. However, a bank cannot successfully charge a premium on loans to cover the losses on other, renegotiated, loans in its portfolio. As loans are renegotiated (an event the occurs with positive probability), the portfolio of the bank changes. In this model, banks will not hold perfectly diversified loan portfolios even if they can because their aversion to risk and their liability are both limited.

Consider an individual bank with a constant level of deposits. Eventually, in this model, one of its client firms will be unable to repay and will renegotiate its loans with the bank because productivity shocks are iid for any given project. The bank will begin shifting its loan portfolio towards this firm and the probability of a subsequent rollover rises with each renegotiation as the positive probability that $\alpha k_{t} \leq R_{t} \ell_{t}$ rises as $\ell_{t}-k_{t}$ rises with each realization of productivity less than $R_{t} \ell_{t} / k_{t}$. The probability of a reallocation away from other firms towards those clients that have suffered low output realizations is path-dependent and increasing with each poor outcome, when the loan terms offered by other banks are taken as given. The bank's portfolio becomes riskier over time. The probability that the bank will be unable to meet a withdrawal of its deposits as contracted,

$$
\operatorname{Pr}\left\{\sum_{j} \min \left\{\alpha^{j} k_{t}^{j}-\gamma, R_{t}^{j} \ell_{t}^{j}\right\}<\left(1+r_{t}^{d}\right) \sum_{j} \ell_{t}^{j}\right\}>0,
$$

rises stochastically. That is, its expectation must be non-decreasing. The sum in inequality (16) is taken with respect to the client firms of the individual bank.

With capital accumulation, banks can grow because household savings is positive. In this endogenous 
growth model, we let the average net productivity of capital exceed the discount rate of households, or, alternatively, the world real rate of interest for the open economy. Starting out with positive initial firm assets (uniform across all firms) and a large number of firms, the growth rate of the capital stock rises with $E \alpha-\left(1+r^{d}\right)$. For example, if we ignore the residual risk faced by households and let utility be logarithmic, we have that the capital stock grows in expectation as

$$
E \alpha-(1+\rho)
$$

where $\rho$ is the pure subjective discount rate of households and $E \alpha$ is average gross return to capital across the economy. Eventually, however, some firms do become insolvent as implied by equation (11). As they do, banks renegotiate these loans and lend more capital to these firms. In a closed economy equilibrium, savings constrains the growth of the aggregate capital stock, so that loan rollovers necessarily reduce the growth rates of other firms. This implies that the co-financing share for solvent firms rises as other firms are unable to repay their current debts. This provides a partially offsetting effect in the closed economy - solvent firms will expand more slowly but make less risky project selections.

In this economy, the probability that a bank becomes insolvent rises over time as renegotiation of individual client loans takes place. Path-dependence of the riskiness of bank portfolios and the probability of eventual bank insolvencies arises from the renegotiation of loans in the presence of the agency problem. This shift in the riskiness of the aggregate portfolio of the banking system would not occur if banks simply closed firms that were insolvent. The riskiness of each bank's portfolio in that case would remain the same over time. Forcing banks to write-down debts by marking loans to market under capitalization requirements may be a way of reducing this type of increasing vulnerability to idiosyncratic shocks.

In the standard banking model adopted here, depositors face a moral hazard problem lending to banks. Each saver cannot monitor the bank's portfolio choices. The solution for this problem is the 
conventional deposit contract that allows a depositor to reclaim her gross deposit with interest at any time and keeps the bank from renegotiating with individual depositors. It is possible to model bank runs in this economy as the probability that some banks cannot service their deposit claims rises over time but depositors do not know which banks. Such a run is not a self-fulfilling run as demonstrated by Diamond and Dybvig [1983], and we do not add the assumptions needed to generate such possibilities.. The introduction of deposit insurance could be justified in this manner or by its effect of lowering the deposit rate of interest in this economy. Without perfect information about the loan portfolio of each bank at all times, deposit insurance can exacerbate the tendency of banks to choose riskier portfolios and raise the transition probabilities of bank insolvencies. Deposit insurance should be associated with greater fragility of the financial sector in the absence of enforced regulations restricting loan renegotiation.

The problem of loan renegotiation may realistically extend to the case of a firm that cannot meet its net interest obligation. This is the event in which

$$
(\alpha-1) k_{t}-r_{t} \ell_{t}<0 \quad \text { but } \quad \alpha k_{t}-R_{t} \ell_{t}>0 .
$$

If capital is not costlessly reversible, then the firm is illiquid, but not insolvent. In this case, loan rollovers can also be optimal. Under this type of rollover, the firm's capital stock in period $t+1$ is higher than otherwise and its choice of project is riskier. The probability of bank collapses rises with costly disinvestment.

Another possible extension of the model is to introduce differential costs of monitoring firm behavior between savers and banks. In the model of Holmstrom and Tirole [1997], firms begin to borrow directly as their capital increases. Such access to direct borrowing could be introduced into this framework (and associated with the equity of entrepreneurs in their firms) to provide another reason for competitive pressure to keep down interest rates for successful borrowers as bank portfolios become heavier in rolled over firm debt. 


\subsection{Foreign Capital Inflows to Domestic Banks}

We now consider this banking sector in the open economy. Again, domestic banks have a cost advantage over foreign lenders in observing the output realizations of domestic entrepreneurs. This advantage can be assumed to be large enough to preclude any direct foreign portfolio lending to domestic entrepreneurs. Alternatively, following Holmstrom and Tirole [1997], foreign creditors might have a cost disadvantage in monitoring firm behavior that leads to direct lending only once a threshold in firm equity is passed. In that case, the increase in monitoring costs is offset by the incentive effect of a larger share of the firm's capital that is owned by the entrepreneur.

When deposit insurance guarantees discriminate between foreign and domestic depositors, foreigners accumulate risky deposit claims against domestic banks. In the event that a bank is unable to meet its entire deposit liabilities, the total current assets of the bank,

$$
\sum_{j} \min \left\{\alpha^{j} k_{t}^{j}-\gamma, R_{t}^{j} \ell_{t}^{j}\right\},
$$

are divided between foreign depositors and the deposit insurer. The inflow of foreign capital to the banking sector will be sensitive to the anticipated ex post seniority rights of foreign creditors vis-a-vis the insurer (typically, the government).

The government can encourage capital inflows in the presence of moral hazard and adverse selection in domestic banking and investment by guaranteeing the real value of the gross exposure of foreign lenders. In the short run, the government can do this by fixing the exchange rate, which removes the incentives for banks to hedge foreign currency risk (as demonstrated by Burnside, Eichenbaum and Rebelo [1999]). If banks borrow in foreign currency denominated loans under a floating rate, they face the risk of insolvency (balance sheet risk) in the event a depreciation that raises the deposit insurance obligation of the government ceteris parabis. We are interested in the consequences of a fixed exchange rate regime with an explicit or implicit government guarantee of the foreign liabilities of the banking 
sector in the event of a switch to a float, and not the welfare economics of this policy. Therefore, we make the assumption that the government implicitly guarantees foreign liabilities denominated in foreign currency in the event that it abandons the exchange rate peg. In this event, there can be a broad financial crisis because banks do not hedge foreign currency risk (in anticipation of this type of bailout) and devaluation reduces foreign currency values on the asset side of the balance sheets for all banks. We impose an upper bound to the amount that the government will guarantee, given by $\bar{d}$. Up to this limit, foreign loans to the domestic banking sector are riskless. That is, there is no currency risk until $\bar{d}$ is reached. For simplicity, we assume that $\bar{d}$ is known with certainty. A limit on the indemnity liability of the government comes from the requirement that the government satisfy its intertemporal budget constraint. Foreign lenders are not protected by the deposit insurance scheme offered to domestic savers.

Foreign capital inflows can raise the aggregate growth rate of the model economy. Banks will borrow at the constant world rate of interest to lend to either firms that have not yet renegotiated their debts or to firms that have. As rollovers accumulate, foreign inflows allow banks to expand their lending to firms that are liquid according to the solution to the agency problem,

$$
k_{t+1}-k_{t}=\frac{1+z}{z}\left[(\alpha-1) k_{t}-r_{t} \ell_{t}\right]
$$

where $(\alpha-1) k_{t}-r_{t} \ell_{t}>0$. Similarly, they are able to continue lending to firms that are either illiquid (in the case of irreversible investment) or insolvent (in either the case of irreversible or reversible investment) with rollovers. In the open economy, foreign capital inflows allow banks to continue lending to solvent firms at the ex ante optimal choice of co-financing, $z$, while providing capital to insolvent firms under renegotiated loans. In contrast with the closed-economy case, the growth of solvent firms is not reduced by renegotiation so that the financial accelerator is larger for the open economy. However, $z$ also does not rise for these firms as banks lend more capital to renegotiating firms. The offsetting reduction in the riskiness of project choices for solvent firms experienced in the 
closed economy disappears, and the riskiness of bank portfolios rises with the opening of the capital account.

Consider the instance of an economy with reversible investment and no firms that have renegotiated debts. The capital stock and gross output grow according to the $A K$ model at the difference between equilibrium net productivity, $E(\alpha-1)$, and the foreign rate of interest (lower than the appropriate risk-adjusted rate of time preference so that capital inflows are positive). However, once there is a rollover, the capital stock will grow faster for the small open economy facing a perfectly elastic supply of deposits at the foreign rate of interest. This is because bank loan renegotiation stops firms from contracting on one end of the spectrum while firms continue to grow (stochastically) under constant returns to capital at the other end.

Foreign lenders, however, face different incentives under the implicit guarantee associated only with a broad crisis in the event of a collapsing exchange rate regime. They lose if a single bank is forced to bankruptcy idiosyncratically, while domestic deposits are insured. However, as the portfolios of individual banks become ever riskier with infusions of foreign deposits, more and more banks reach potential crisis. This follows from the result that renegotiation leads to increasingly risky bank portfolios and rising contingent liabilities for the banks' creditor (the deposit insurer). Banks enter insolvency with positive probability. The probability of leaving insolvency decreases as more of the bank's firms renegotiate loans with positive probability and choose ever riskier projects in the absence of co-financing. Foreign inflows that sustain these banks allow more and more banks to become insolvent. The contingent liability of government, $d_{t}$, is a random variable that also follows a sub-martingale. It must reach its upper bound in finite time.

This process is driven by the ultimate prospect of a bailout of foreign lenders. It could happen immediately if foreign lenders realized a larger rate of return from the government bailout than the world rate of interest. We think that it is unrealistic to assume they do. Therefore, it happens progressively and 
with stochastic timing because there are positive real net returns to domestic investment.

In the equilibrium path for the economy with foreign capital inflows, this process implies that we should observe increasing financial capital inflows as the crisis draws nearer. Each rollover raises the ratio of bank deposit liabilities to physical capital, $\ell / k$, in this model. As rollovers become more probable, this ratio rises faster. In the model, output is proportional to capital, $y=\alpha k$, so that the debt to gross domestic product ratio is rising. So is its foreign component. We also note that the capital stock will be growing at a faster rate with an open capital account and implicit guarantees of foreign currency bank debts, in contrast to the case for the closed economy. However, gross domestic product may not be rising with the capital stock as more and more firms no longer co-finance investment and choose riskier projects.

\subsection{Foreign Capital Inflows and Twin Crises}

The link to currency crises comes about by the same mechanism proposed by Dooley [2000], Burnside, Eichenbaum and Rebelo [1999], Chinn and Kletzer [2000] and others. These "thirdgeneration" models of financial crises are based on first-generation models of a speculative attack with the twist that domestic credit creation follows the attack and is contingent on the collapse. It is assumed that the cost of the bailout is ultimately monetized and that the implied ex post growth rate of domestic credit is inconsistent with the exchange rate peg.

The mechanics of a crisis need to be described a bit more. There is an upper bound on the credit that will be extended by foreign lenders to the domestic banks when the ultimate bailout is bounded from above by $\bar{d}$. This is the sum of the government's implicit guarantee, central bank reserves and the residual capital of the banking system in the event of a financial crisis. This upper bound is reached in finite time with probability one as a consequence of the bank debt rollover dynamics for the agency model as explained above. Eventually, the foreign debt of the banking sector exceeds the value of the banking sector plus central bank reserves minus domestic deposits. ${ }^{7}$ This excess claim at time $T$ is $d_{T}$. 
Suppose a run occurs in period $T$, so that the debt of the government rises by the amount $d_{T}$ which will be paid through domestic credit creation. The expected rate of depreciation after the abandonment of the fixed exchange rate is increasing in $d_{T}$. A rise in the rate of depreciation lowers domestic money demand at the instant of the speculative attack. This reduction is also increasing in $d_{t}$. Therefore, a portion of central bank reserves is taken by parties other than holders of foreign bank deposits in the currency crisis. This amount is given by $R_{T}^{d}=\psi\left(d_{T}\right)$, where $\psi^{\prime}\left(d_{T}\right)>0$. The reserves taken by foreign holders of short-term foreign currency bank debt, $R_{T}^{f}$, exhaust the remaining reserves used in defense of the peg, $\bar{R}_{T}$. These equal the difference between total foreign claims against the domestic banking sector, denoted $b_{T}$, and the government's guarantee, so that $R_{T}^{f}=b_{T}-d_{T}$.

At the time of the twin banking and currency crisis, we have the equilibrium condition,

$$
\bar{R}_{T}=R_{T}^{d}+R_{T}^{f}=b_{T}-d_{T}+\psi\left(d_{T}\right)
$$

where $d_{t}$ is a stochastic function of $b_{t}$. That is, both depend on the history of lending, investment and production in the domestic economy leading up to the crisis. The timing of the crisis is stochastic and path dependent.

Whether a crisis can occur in this economy depends upon the size of the maximal government guarantee, $\bar{d}$, relative to reserves. This is because an increase in government debt equal to $\bar{d}$ leads to a particular rate of domestic credit creation if it is entirely monetized. This rate of domestic credit creation may or may not lead to a first-generation currency crisis at the moment it is incurred. It can be too small, implying a collapse of the fixed exchange rate regime at some later date. If this is the case, foreign creditors will not be bailed out until the collapse and incur the net opportunity cost of lending $\bar{d}, r^{*} \bar{d}$. So, if $\bar{d}$ is too small, the eventual bailout will not be sufficient in present value to keep foreign lenders in the market.

Does this mean that foreign capital inflows are zero if $\bar{d}$ is small? The answer is no as long as banks hold deposit liabilities to domestic savers covered by deposit insurance. Foreign deposits can be 
serviced in full as a bank's portfolio deteriorates up to the point that the current value of the bank's net assets,

$$
\sum_{j} \min \left\{\alpha^{j} k_{t}^{j}, R_{t}^{j} \ell_{t}^{j}\right\}
$$

just equals the foreign deposit liability. Domestic savers are fully covered by deposit insurance, and the withdrawal of foreign deposits busts the bank. This type of foreign exit from the banks occurs idiosyncratically across banks in this model because the only productivity risk is idiosyncratic across firms.

A currency crisis occurs when the rate of domestic credit creation necessary to finance the government's liability at time $T, d_{T}$, is exactly consistent with a collapse of the fixed rate at time $T$. The timing depends on the stochastic processes for $b_{t}$ and $d_{t}$ (which depend on the entire structure of the economy), as well as the level of reserves. So, if $\bar{d}$ is sufficient to allow a currency crisis soon enough that foreign lenders realize their opportunity rate of return on loans with bailout, then there is a widespread financial crisis as all foreign loans are pulled from the banking system. Put differently, if the government guarantee is sufficient to encourage any foreign capital inflows, then it leads to an inevitable currency and banking crisis. If $\bar{d}$ is too small to generate an eventual currency crisis, then it has also no impact on capital inflows. The possibility of equilibria in which lending never begins can be ruled out by the condition that

$$
E[\min \{r, \tilde{\alpha}-1\}] \geq r^{*},
$$

where $\tilde{\alpha}-1$ is the net rate of return to bank loan portfolios inclusive of the returns from rollovers.

We could delink this crisis from the exchange rate peg by changing the assumptions about government guarantees. If there can a bailout of the banks in the event of a systemic banking crisis that insures foreign creditors, then a banking crisis can occur under a floating exchange rate regime. If the subsequent liabilities of the government are monetized, the rate of exchange rate depreciation naturally rises. If the bailout is financed by taxes on domestic residents, then consumption growth is depressed 
(since the timing is stochastic, Ricardian consumers will not fully smooth consumption against the tax increase).

\subsection{Post-crisis Contraction}

At the moment of the financial crisis, there is a sudden reversal of capital inflows as foreign lending stops and households reduce their demand for domestic currency deposits. The contraction in domestic deposits causes a contraction in the capital stock given by

$$
k_{t+1}-k_{t}=\ell_{t+1}-\ell_{t}+\left[(\alpha-1) k_{t}-r_{t} \ell_{t}-\pi_{t}\right]
$$

for a solvent firm where $\ell_{t+1}-\ell_{t}<0$. This increases the ratio of self-financing to capital sharply,

$$
z_{t+1}=\frac{\left[(\alpha-1) k_{t}-r_{t} \ell_{t}-\pi_{t}\right]}{k_{t+1}}
$$

implying that new bank lending will be forthcoming if the banks can borrow. Insolvent firms may also be able to borrow if their debt is restructured with write-downs that leave them at least solvent. However, with the guarantees of the government exhausted, new foreign deposits to the banks are not supported. Domestic household income and consumption drop right along with the capital stock. If the banks remain in business for intermediating loans, then domestic savings deposits will flow to domestic firms allowing growth from the new low aggregate capital stock. These deposits are smaller, in proportion with domestic income, and are only made if there is deposit insurance as before. As noted foreign inflows will be lower than before the crisis so that the growth rate of the economy is also lower than before the crisis.

If the government does not restructure the domestic financial sector, the growth rate of output could fall even more after the crisis because the intermediation benefits of banks are lost as argued by Calvo [1998a]. The loss of domestic banking would force the use of alternative, higher cost, means of intermediation. 


\subsection{Empirical Implications}

In the model economy, domestic financial and currency crises occur simultaneously and are inevitable under the policies assumed. These include the absence of effective prudential regulation of the banks. The foreign indebtedness of the banking sector rises in proportion to gross domestic output and the capital stock before the financial crisis. The production and banking model also implies a rise in the growth rate of the capital stock as the crisis becomes more likely. This will coincide with an increase in the aggregate riskiness of the banking sector's loan portfolio.

The model also has implications for the market value of firm and bank equities. Because loans can be renegotiated, the value of a firm is not zero when

$$
\alpha_{t} k_{t}-R_{t} \ell_{t} \leq 0
$$

The firm is an ongoing enterprise that could potentially pay off its debts, allowing the entrepreneur to accumulate capital in the firm once more. Therefore, the stockmarket value of the firm includes the option value of "redemption" and will remain positive.

The equity value of the firm is given by the expected present value of the dividends it can pay subject to the imposition of the transversality condition. For firms that have positive net income, the capital stock is rising and so is firm equity. This increase is larger than the rise in productivity for a positive shock. This can be seen simply by ignoring dividends and calculating the discounted expected equity of the entrepreneur's ownership (how the stockmarket value of a firm that does not pay a dividend changes). This evolves according to

$$
x_{t+1}=\left(\alpha-R_{t}\right) k_{t}+R_{t} x_{t}
$$

which equals

$$
x_{t+1}=\left[\left(\alpha-R_{t}\right) \frac{1}{z}+\alpha\right] x_{t}
$$


with lending in the agency model. The present value of the owner's equity is given by

$$
E_{t}\left(\frac{x_{t+1}}{R_{t}}\right)=E_{t}\left[\left(\frac{\alpha}{R_{t}}-1\right) \frac{1}{z}+\frac{\alpha}{R_{t}}\right] x_{t}>x_{t} .
$$

Differentiating with respect to $\alpha$ shows that the equity value of the firm rises more than proportionately with the discounted productivity of capital. For firms that remain solvent but realize negative net incomes, $(\alpha-1) k_{t}-r_{t} \ell_{t}<0$, the value of equity falls along with the capital stock.

The average value of all producers' equity evolves over time as capital accumulates and some firms renegotiate bank loans. Beginning with all firms co-financing investment, the total stockmarket value of firms rises as the average capital stock rises. It also rises to the extent that the equity value of firms that have low outputs and downsize (but remain solvent) reflects an increase in the likelihood that they will become insolvent in the future and renegotiate their loans. For such firms the option value of redemption rises. Once firms do become insolvent and renegotiate their bank debts, the value of these firms remains non-negative while the average equity value of firms that have been successful continues to rise with the capital stock. Ignoring the expectation that there will be a collapse in the capital stock at date $T$, the total stockmarket value of producers would be rising over time (in the case of large numbers with uncorrelated firm-specific shocks) under foreign capital inflows as long as the net expected return to capital exceeds the rate of interest. However, these dynamics imply a rise followed by a decline in the total value of firm equity prior to crisis under rational expectations..

The equity value of banks also evolves dynamically as loan rollovers take place. However, banks face an upper bound on the share of the returns to successful projects they can claim in proportion to the firms' capital stocks in the face of competition from other banks. The banks are accumulating losses over time and their equity value must decline in expectation once one bank has had to roll over the loan of a firm that cannot repay its short-term debt. Clearly, the average equity value of banks is lower when some client firm has to renegotiate. In the model set up here, the probability of more renegotiations and of increasing liability for the deposit insurer mean that the expected equity of the bank is decreasing 
thereafter. It decreases as

$$
\operatorname{Pr}\left\{\sum_{j} \min \left\{\alpha^{j} k_{t}^{j}, R_{t}^{j} \ell_{t}^{j}\right\}<\left(1+r_{t}^{d}\right) \sum_{j} \ell_{t}^{j}\right\}
$$

rises.

Therefore, the model of an evolving banking crisis driven by loan rollovers fueled by foreign capital inflows implies that the ratio of the equity value of banks to the equity value of corporations should be declining in trend before the crisis. Foreign capital inflows should be rising in proportion to gross domestic product if the assumptions of constant returns to capital and unchanging investment opportunities hold. Output should collapse sharply after the crisis.

The Bernanke and Gertler model of financial fragility shows how aggregate productivity cycles are exacerbated through the financial accelerator. This implies that the capital stock falls but that the growth rate could recover in a simple closed economy $A K$ model. In our model, foreign capital inflows would need to return to avoid a reduction in the growth rate of the economy post-crisis.

\section{The Assumptions of the Theoretical Model and the Pre-crisis Financial Systems of East Asia}

The theoretical model generates endogenous accumulations of foreign debt by a domestic banking sector that is progressively less stable, leading to an eventual crisis. Three of the model's assumptions are crucial in this process. First is the predominance of corporate borrowing from domestic banks, arising from the informational advantage of banks over other lenders. Second is the prospect of government deposit insurance, or government bailouts of the domestic banking sector; and government guarantees of foreign loans to the domestic banking sector. Third is supervisory forbearance and the absence of effective prudential regulation of the banking sector. In this section, we briefly examine the pre-crisis financial systems of Korea, Taiwan Province of China, Thailand, Malaysia, and Singapore along these dimensions. Table 1 briefly summarizes this section's findings. The economies with 
financial systems that fit the model's assumptions most closely are assigned the highest negative ratings. We find that the model's assumptions characterize the financial systems of Korea and Thailand very well (negative ratings: 9), the financial system of Malaysia reasonably well (negative ratings: 6). The model's assumptions fail to fit the financial systems of Taiwan Province of China, and Singapore (negative ratings: 5 ).

\subsection{Corporate Reliance on Domestic Bank Borrowing}

With regards to the predominance of bank lending, only Korean firms were highly reliant on domestic bank borrowing. In Thailand, domestic banks were not always the dominant lender, as corporations borrowed directly from foreign banks in the offshore market. In Thailand, however, the importance of finance companies increased in the 1990s, as licensing requirements were eased. Malaysian, Taiwanese, and Singaporean firms were not as reliant on domestic banks, as they actively tapped bond and equity markets.

Just prior to the crisis, the reliance of Korean corporations on domestic commercial and merchant bank financing was large and increasing. In 1997, borrowing from banks accounted for close to 50 percent of total corporate financing; this was up from about 35 percent in the mid-1990s (Pomerleano

[1998]). Moreover, most of the remaining corporate financing-corporate bonds, commercial paper, and foreign borrowing-was explicitly guaranteed by banks. For example, in 1996, 87 percent of the bonds issued by corporations had bank guarantees. The default risk on these bonds was borne by the banks, since if the corporation failed, the bondholder would have recourse to the guaranteeing bank (Dekle and Ubide [1998]). Equity financing was small; in early 1997, equity financing accounted for only 7 percent of total corporate financing, down from about 20 percent in the early 1990s. Thus, by early 1997, the debt-equity ratios of manufacturing corporations was over 300 percent, and most of this debt was explicitly or implicitly owed to domestic banks (Pomerleano [1998]).

Compared to Korea, the reliance of Taiwanese corporations on domestic bank financing was 
markedly lower. In 1996, borrowing from banks accounted for less than 22 percent of total corporate financing, down from about 50 percent in the early 1990s (Chu [1999]). By the late 1980s, large corporations could raise most of their funds from the equity market (Chu [1999]). Moreover, Taiwan Province of China developed a successful venture capital industry and initial public offering market. In 1997, small- and medium-sized firms raised \$2 billion and \$27 billion from venture capital and initial public offerings respectively. Thus, by early 1997 , the debt-equity ratios of corporations was down to about 85 percent, lower than even the debt-equity ratios in many industrialized countries.

The reliance of Thai corporations on bank and finance company financing was among the highest of the crisis-inflicted Asian countries, although some of this reliance was to foreign banks. Between 1992 and 1996, borrowing from banks and finance companies accounted for 74 percent of total corporate financing (Pomerleano [1998]), and the average debt-equity ratio was about 180 percent (Pomerleano and Zhang [1998]). In 1995 and 1996, borrowing from finance companies accounted for about 27 percent of this corporate borrowing. Finance companies tended to focus more on consumer and real estate financing, while banks loaned more to the manufacturing sector. A significant fraction of this corporate borrowing was from foreign-particularly Japanese-banks. Most of the borrowing from foreign banks was through the Bangkok International Banking Facility (BIBF)-whose ”out-in” lending is entirely foreign currency denominated. In 1996, BIBF borrowing accounted for about 18 percent of all bank borrowing by Thai corporations (IMF [2000a]).

Between 1992 and 1996, Malaysian corporations raised about 40 percent of their funds from domestic banks, finance companies, and merchant banks (all deposit-taking institutions) (Pomerleano [1998]). This ratio of private corporate borrowing may understate the dependence of the Malaysian economy on the banking sector. Consumers and non-incorporated businesses were also large bank borrowers. Finance companies accounted for about 20 percent of domestic borrowing, and loaned mostly to consumers and non-incorporated businesses. Foreign-owned banks accounted for about 15 
percent of all domestic borrowing, although the main source of funds for foreign banks was domestic deposits. Compared to corporations elsewhere in Asia, Malaysian corporations have relied somewhat more on bond, and significantly more on equity financing; the debt-equity ratio was relatively low, at under 100 percent (Pomerleano and Zhang [1999]).

Between 1992 and 1996, Singapore corporations raised about 40 percent of their funds from banks (Pomerleano [1998]). Only four banks accounted for 80 percent of these loans, all of them domestic. The remaining loans were from smaller banks, foreign banks, and finance companies. Although Singapore has a large offshore market, regulations have kept the domestic currency and foreign currency markets separate, borrowing from offshore in domestic currency by domestic corporations was restricted, although foreign currency borrowing was not. As in Malaysia, Singapore corporations have tended to rely more on bond and equity financing, thus, keeping the debt-equity ratio to under 90 percent.

\subsection{Government Explicit and Implicit Guarantees of Domestic Bank Liabilities}

With regards to government guarantees, in Korea, Taiwan Province of China, Thailand, and Malaysia, bank deposits were implicitly guaranteed by the government, given that no domestic bank was ever allowed to fail and close. Failing banks were usually taken over by the government and forced to restructure, or merge with another bank. Singapore also did not provide explicit bank deposit guarantees, but in the absence of domestic bank failures or takeovers, it is difficult to assess the extent of implicit guarantees to depositors. Foreign loans to the domestic banking sector were implicitly guaranteed in each instance. However, such loans were important only for Korea, and to a lesser extent, in Thailand. Banks in Taiwan Province of China, Malaysia, and Singapore borrowed little from abroad.

Prior to the crisis, the Korean deposit insurance system was segmented; different deposit insurance systems covered different financial institutions. Moreover, given the relative newness of the various systems (started in mid-1990s), and the low deposit insurance rates, the accumulated deposit insurance 
premia was negligibly small. Thus, for all practical purposes, Korea did not have an explicit deposit insurance system. However, depositors probably viewed their deposits as implicitly insured, because the Korean government had never allowed a bank to fail (Park [1994]). Between 1960 and the mid-1980s, the idea of deposit insurance was moot-banks were publicly owned, and monetary authorities controlled every aspect of bank management. Although banks were privatized in the early 1980s, and financial markets were deregulated, the government continued to exercise control over banks by appointing bank management and by the system of government policy loans (Dekle and Ubide [1998]). Policy loans were used by the government to direct bank lending to preferred sectors, with the provision that should the firms receiving the loans default, the lending bank will be bailed out. Although policy loans have been largely phased out by the mid-1990s, the historical involvement of the government has meant that banks developed few skills in credit analysis. Lending decisions were still based on the availability of collateral, normally real estate (45 percent of all loans), and government moral suasion.

Domestic banks have intermediated virtually all foreign borrowing by Korean corporations, in won or in foreign currency. Of the loans borrowed directly from foreign banks, almost all carried guarantees by domestic banks (Collins and Park [1989]). In the mid-1990s, some companies were able to directly borrow in overseas bond markets, but this borrowing had to be bank guaranteed. These various types of bank-intermediated foreign loans were not explicitly government guaranteed, but given that no domestic bank had failed, the government was in effect implicitly guaranteeing these loans. In fact, in August 1997, in the midst of the crisis, the authorities made explicit its commitment by guaranteeing all foreign liabilities of Korean banks.

As in Korea, for all practical purposes, Taiwan Province of China did not have an explicit deposit insurance system. Participation in the Taiwanese deposit insurance system was voluntary, and as a result the accumulated insurance premia was very small (Yang [1994]). However, as in Korea, depositors viewed their deposits as implicitly insured, since most deposits were with banks owned by various 
branches of the government. Although the banking system was partially privatized in the early 1990 s, government-owned banks still accounted for about 60 percent of total bank loans in 1996 (Chen [2000]). Customers of the government-owned banks were mainly public enterprises and large private manufacturing firms (Shea [1994]). Private banks were numerous, but all were very small. When insolvent, these private banks were bailed-out by the government (Yang [1994]). Most of the bank lending (66 percent) was collateralized, with real estate, or more often, with equity.

Of the Taiwanese foreign borrowing, only 5 percent was explicitly guaranteed by the government (Haggard [2000], p. 134). In any event, the total amount of foreign borrowing remained small (gross foreign debt: 10.6 percent of GDP). Banks intermediated only about a half of this foreign borrowing.

Thailand has never had an official, explicit, deposit insurance system. However, the Thai government has always bailed-out depositors. Insolvent banks were usually recapitalized, and allowed to operate as normal. During the crisis, six of fifteen commercial banks were taken over by the government. In addition, the government issued a blanket guarantee of all bank deposits. Finance companies were allowed to fail, but the government has always guaranteed their deposits, ex post. During the crisis, 56 out of 91 finance companies failed, but all deposits were guaranteed, although credits held by directors and management of failed institutions were not covered(IMF [2000a]).

There were two main sources of foreign borrowing by Thai corporations. First, corporations borrowed in baht from non-resident deposits in Thai banks. Non-resident bank deposits have historically received the same guarantees as resident deposits. Second, corporations borrowed in foreign currency from Thai and foreign banks through the BIBF. None of this foreign currency borrowing was explicitly guaranteed by the government. However, the foreign currency borrowing intermediated through Thai banks (1/3 of total BIBF borrowing) was, like all domestic bank liabilities, implicitly guaranteed, since these domestic banks could not fail. The government did not implicitly guarantee the borrowing through foreign banks, since most of this borrowing went to joint ventures-for example, Thai-Mitsubishi Motors; 
the responsibility for paying back this borrowing was viewed as belonging to the parent firm-e.g., Mitsubishi Motors, Japan.

There was no explicit deposit insurance system in Malaysia. However, Malaysia has never allowed a bank or finance company to fail, although finance companies have been merged. Thus, all deposits at domestic financial institutions were implicitly guaranteed, at least for residents. In fact, ex post, the government has guaranteed even the deposits at foreign banks; during the crisis, the government issued a blanket guarantee of all deposits.

Borrowing by domestic banks from foreign banks in foreign currency has never been sizable in Malaysia, given very strict foreign borrowing regulations. The small amount of borrowing that took place was never explicitly guaranteed. Historically, Malaysia has often imposed controls on portfolio outflows. For example, in 1994, controls on short-term portfolio inflows were imposed; and in 1998, minimum holding periods (12- months) and exit levies (30 percent) on the repatriation of bank deposits held by non-residents were imposed (IMF [1999a]). In the case of repatriation restrictions, the subsequent depreciation of the ringgit has meant that non-residents experienced capital losses on their ringgit deposits. Thus, for certain types of foreign borrowing, such as non-resident ringgit deposits, there were no implicit guarantees either.

Singapore never had an official, explicit, deposit insurance system. However, as elsewhere in Asia, no domestic bank nor finance company has ever been allowed to fail, although the government has not always bailed out depositors with deposits at failed foreign banks. Thus, it may be the case that there is a selective implicit guarantee of deposits was selective, limited to deposits at domestic financial institutions.

Regulations have prevented Singapore corporations from borrowing offshore in domestic currency. Given Singapore's ample saving and low interest rates, offshore foreign currency borrowing by corporations remained very small; this borrowing was not guaranteed, explicitly nor implicitly. 


\subsection{Government Prudential Regulations and Enforcement}

With regards to weak prudential supervision, in Korea and Thailand, prudential regulations were lax, and poorly enforced, because of fragmented supervisory systems, and supervisory forbearance. Supervisory systems were strict and well-enforced in Malaysia, Taiwan Province of China, and Singapore.

Lax prudential standards and supervisory forbearance were major deficiencies in the Korean banking system (Dekle and Ubide [1998]). Supervision of financial institutions was fragmented; the Bank of Korea supervised commercial banks, but the Ministry of Finance supervised merchant banks. Defects in the soundness of banks were not immediately remedied once detected by the bank supervisors, and change to prudential regulations were made to allow banks to report profits and capital positions that were misleading. For example, provisioning requirements for non-performing loans were relaxed over 1995-96; that for "doubtful" loans were decreased from 75 percent from 100 percent. Although there were regulations on bank loan exposure to large corporate groups, these regulations were rarely enforced. For example, the Hanbo group, which collapsed in early 1997, had outstanding loans from Korea First Bank that were five times larger than what was considered prudent. Knowledge of such supervisory forbearance, together with less than fully transparent accounting, meant that Korean banks were not encouraged to take speedy action to improve their solvency.

Although on paper, Taiwan Province of China's prudential standards were no stronger than Korea's, it's supervisory authorities exercised much less forbearance (Chu [1999]). The Central Bank of China (CBC) was Taiwan Province of China's main supervisory authority, rather than the Ministry of Finance. In contrast to most Finance Ministries, the $\mathrm{CBC}$ was unusually independent from political influence. The CBC governor appointed the senior officers of all government-owned banks, and forced these banks to observe prudential standards stricter than those mandated by law. For example, most government-owned banks were forced to maintain capital-asset ratios above 12 percent (above the law's 
8 percent), and a liquid asset-to-reserve ratio of 9.5 percent (above the law's 7 percent). The CBC also kept government policy loans under tight limits.

Lax prudential standards were major deficiencies of the Thai banking system (Lindgren, et. al. [2000]). The rules for loan classification and accounting were too lenient and were often ignored. For example, loans had to be in a non-accrual state for 12 months before they were classified as nonperforming. Banks and finance companies built up large portfolios of questionable loans which were often simply rolled-over, rather than classifying them as non-performing. There were no limits on loan exposures to specific sectors such as real estate, although there were limits to individual borrowers. Bank supervision was fragmented between the Ministry of Finance and the Bank of Thailand. The Ministry of Finance was entrusted with the overall authority for supervision, but the day-to-day responsibility for supervision was delegated to the Bank of Thailand. All decisions by the Bank of Thailand needed to be ratified by the Ministry of Finance.

Malaysia's prudential regulations were drawn from British sources, and were, on paper, more stringent than in other Asian economies (Scott [1999]). Moreover, these regulations were strengthened in the late 1980s and in the mid-1990s. In particular, broad regulatory and intervention powers were consolidated at Bank Negara Malaysia (Lindgren, et. al. [2000]). There were strict limits on connected lending, and loan exposure limits (30 percent of a bank's capital) to corporate groups. A two-tiered regulatory system, which provided extra privileges to banks that increased their capital, was introduced. As a consequence, capital-asset ratios of deposit-taking institutions approached 10 percent.

Singapore's prudential regulations were also drawn from foreign sources, primarily Britain and the United States, and have been far more conservative than elsewhere in Asia. By law, banks were required to maintain capital-asset ratios above 12 percent. Broad regulatory and intervention powers were consolidated at the Monetary Authority of Singapore. In addition, foreign banks were allowed to operate only on the strength of their home regulations. Comfort letters were required stating that home 
offices will meet liquidity or capital shortfalls of their offshore affiliates (IMF [2000b]). However, bank disclosure was weak; bank assets were recorded on accounting statements at historical cost, rather than at market value, and contingent liabilities, such as derivatives positions, were not disclosed (IMF [1999b]). Nevertheless, these problems with bank disclosure were worse in other Asian economies and led to the adoption of more rigorous requirements in recent years.

\subsection{Relation to Earlier Studies}

Recent studies have examined more systematically, the relationship between banking and regulatory structure, and banking crisis. Demirguc-Kunt and Detragiache [2000] create a index representing the extent of explicit deposit insurance for 61 countries. Using cross-section probit econometric techniques, the authors find that countries with explicit deposit insurance systems are more likely to incur a crisis in their banking systems. The authors find that proxies for bank regulation such as rule of law, quality of bureaucracy, and degree of corruption perform an important role in curbing the negative effect of deposit insurance on bank stability. Finally, the authors find that in more concentrated banking systems, the probability of banking crisis is smaller. This finding is somewhat surprising, since in more concentrated systems, banks are "too big to fail," and may be implicitly insured, thus worsening moral hazard.

Rossi [1999] creates a "bank safety net" index for a sample of 15 countries. The index captures the presence of explicit deposit insurance, of lender of last resort facilities, and whether or not there is a history of bank bailouts. The index is noteworthy in that it partially captures the implicit insurance assumptions of our model. The author finds that the index is significantly positively correlated with bank fragility.

In a cross-section study of 60 countries, Barth, Caprio, and Levine [2000] find that securities market development, especially equity market liquidity; the issuance of equity (in the primary market) as a share of GDP; and the issuance of long-term bonds (in the primary market) as a share of GDP, all decrease the probability of a banking crisis. This is consistent with the assumption of our model that 
higher corporate security financing, and lower bank dependence, decreases the probability of crisis.

\section{Empirical Implications of the Model}

Our theoretical model implies that banking and currency crises coincide and inevitably occur in the absence of effective prudential regulation. Before the crisis, private foreign debt rises as a ratio of gross domestic production. Foreign financial capital inflows will be a constant fraction of trend output in the case that consumption growth equals income growth. Otherwise, the ratio of inflows to output can rise or fall in trend. The investment to output ratio is constant before the crisis. The shadow value of domestic banks should be declining before the crisis. This can be measured by comparing the stock market value of domestic banks to the stock market value of the domestic sector.

After a financial crisis, the model implies that output contracts and that the growth rate of output is lower in recovery than it was before the crisis. This is because contingent government bailout has been exercised so that the resources that previously subsidized foreign capital inflows are no longer available to subsidize new inflows at the same level. The currency crisis should also lead to a contraction in money demand and an increase in the rate of monetary growth. The second is consistent with the monetization of the sudden increase in government liabilities.

The riskiness of the loan portfolio of domestic intermediaries is rising in this model. An increasing share of bank loans go to firms that have realized low capital productivities in the past, while a decreasing share go to firms that have realized high productivities of capital. In the endogenous growth model used, the productivity of capital is an iid random variable. If we allow for a small degree of serial correlation in the productivity of inputs for individual firms, then the marginal productivity of capital will be decreasing in trend.

\subsection{Empirical Evidence for the Model}

The model can be examined along a number of dimensions using indirect measures of the factors 
of interest. The model predicts several relationships. The key relationship is that increases in capital inflows are intermediated through the banking system and result in increases in lending to the private sector. This is the case to the extent that capital inflows to the domestic sector are not sterilized, resulting in reserve accumulations rather than financing debits on the current account.

The model predicts an increasing ratio of foreign capital inflows and domestic lending as a ratio of output prior to crisis. It also implies that domestic investment will become increasingly risky. This may be reflected by falling capital productivity in the data. Bank portfolios are predicted to be deteriorating before the crisis, with the banking system carrying a rising share of non-performing assets. The market

value of total bank equity shares should be falling absolutely and in ratio to the total value of outstanding equity in domestic corporations.

The model also makes post-crisis predictions. There should an immediate contraction in output and investment. The currency crisis in this model results from the anticipated post-crisis monetization of government bailouts of lenders. Consistency with this hypothesis requires that we observe an increases in the rate of domestic credit creation and growth rate of the monetary base after the crisis.

The predictions should hold most strongly for the two economies that fit the assumptions of the model most closely, that is, for Korea and Thailand. The predictions should hold less strongly for Malaysia, and the predictions should fail for Taiwan Province of China and Singapore. In this section, we examine if these predictions hold, using pre- and post-crisis data. The data sources for all charts are described in the Appendix.

\subsection{Pre-Crisis Capital Inflows and Domestic Lending}

An important implication of the model is that capital inflows are manifested in lending by banks and non-bank financial intermediaries. We measure capital inflows using the balance of payments data reported by the IMF, while deposit bank lending to the domestic private sector is measured by domestic credit. Capital inflows are net-gross inflows minus gross outflows. Charts 1a to 1e depict the ratios 
of lending- and capital inflows-to GDP for Korea, Taiwan Province of China, Malaysia, Thailand, and Singapore. In Korea, the capital inflow-GDP ratio started to rise sharply in 1993, while the lending-GDP started to rise in 1995. In Taiwan Province of China, the lending-GDP and the capital inflow-GDP ratios were constant pre-crisis, while the capital inflow ratio rose sharply post-crisis. In Malaysia, the lending-GDP ratio increased moderately from 1990 to 1994, and more strongly from 1994. The growth in the capital inflow ratio was very strong between 1990 and 1993, but the capital inflow ratio plummeted in 1994, when the government imposed capital controls; subsequently, strong capital inflow growth resumed. In Thailand, the lending-GDP ratio grew strongly from 1990 to 1997, correspondingly, the capital inflow ratio grew strongly since 1994. In Singapore, while the lending-GDP ratio grew moderately since 1990, the capital inflow ratio declined sharply from 1990 to 1994 . Subsequently, the capital inflow ratio resumed its growth. As our model predicts, the physical investment-GDP ratios were relatively constant in each case.

As is well-known, capital inflows can be sterilized by central banks; this sterilization can break the link between capital inflows and lending. We do not present a detailed discussion of how effectively capital inflows were sterilized in the five cases; accounts are provided by Spiegel [1995] and Moreno [1996]. There is a strong link between capital inflows and lending, especially since 1994, for Korea, Malaysia and Thailand, suggesting that these countries have not been successful in sterilizing capital inflows. Charts $2 \mathrm{a}$ and $2 \mathrm{~b}$ depict the levels of official foreign exchange reserves, and the ratio of foreign exchange reserves to short-term (of maturity less than one year) external debt. Central banks that engage heavily in sterilized intervention should have high and rising foreign exchange reserves. Reported official Korean reserves are net of Bank of Korea foreign currency deposits at overseas branches. As is well-known, the Bank of Thailand had outstanding net forward contracts totaling \$7 billion in 1997, and $\$ 4$ billion in 1996; the resources available to the Bank of Thailand for intervention may be overstated by the level of official reserves. Compared to Taiwan Province of China and Singapore, Korea, Malaysia, 
and Thailand all had low and constant or declining foreign exchange reserves (between 1996 and 1997), in dollar terms or as a ratio of short-term external debt, suggesting that these countries have not been successful in sterilizing capital inflows. Taiwan Province of China, and Singapore, both had high and rising (especially Singapore) foreign exchange reserves.

Thus, the evidence on capital flows and lending is consistent with our model. Korea and Thailand had the strongest association between capital flows and lending, while capital controls broke the strong association in Malaysia in 1994.

\subsubsection{Riskiness of Domestic Investment and Falling Marginal Productivity of Capital}

In our model, adverse selection under limited liability in financial intermediation imply bank portfolios that become progressively riskier in our model. In the aggregate, lending and investment are increasingly allocated to firms that have experienced low productivities in the past, rather than to firms that have had high productivity experiences. If productivity has a small serial correlation, then the productivity of capital for firms will be decreasing over time.

Between 1992 and 1996, the productivity of capital for firms in Korea, Taiwan Province of China, and Singapore all declined, with the sharpest decline for firms in Thailand. The productivity of capital for firms in Malaysia slightly rose. (The data are all from Pomerleano and Zhang [1999]). For Korean firms, their average return on assets (ROA) declined from 4.5 percent in 1992 to 4.2 percent in 1996, and their average return on investment (ROI) declined from 6.4 percent in 1992 to 5.6 percent in 1996. For Taiwanese firms, their average ROA declined from 7.6 percent in 1992 to 7.3 percent in 1996, but their average ROI was constant at 8.6 percent between 1992 and 1996. For Thai firms, their average ROA sharply declined, from 9.5 percent in 1992 to 6.0 percent in 1996, and their average ROI sharply declined from 11.6 percent to 7.0 percent. For Singapore firms, their average ROA declined from 6.7 percent in 1992 to 6.4 percent in 1996, and their average ROI declined from 9.0 percent in 1992 to 8.6 percent in 1996. For Malaysian firms, their average ROA actually rose slightly from 15.5 percent in 
1992 to 16.1 percent in 1996 , and their average ROI also rose slightly from 11.7 percent in 1992 to 12.1 percent in 1996.

In the case of Korea, the ROA declined only one percentage point over the 1990s. However, what was unique about Korea was that its ROA was uniformly low between 1992 and 1996. If we compare Korea to Taiwan Province of China, we find that the gap in ROA was over 3.0 percent in the 1990s.

\subsubsection{Deterioration of Bank Portfolios}

The model predicts that, in the presence of government guarantees, the ratio of lending to GDP will rise; moreover, the quality of bank portfolios will decline. The trend in the share of non-performing loans (NPLs) gives a measure of the quality of bank portfolios. Chart 3a compares the share of NPLs for Korean and Taiwanese commercial banks. In the early 1990s, Korean banks had a much higher NPLs share than Taiwanese banks, owing to the Korean government's rationalization plans for the chemical and heavy industries in the mid-1980s, in which Korean banks were forced to assume the losses of their corporate borrowers. Subsequently, as the problems of the mid-1980s waned, Korea's NPLs declined and Taiwan Province of China's NPLs rose; by 1996, the share of NPLs in Taiwan Province of China approached that in Korea. Chart 3b compares the share of NPLs for Malaysian and Thai deposit-taking institutions. In the early 1990s, Malaysia's NPLs were higher than Thailand's. Subsequently, Malaysia's NPLs declined and Thailand's NPLs rose sharply, so that by 1996, Thailand's NPLs were double that in Malaysia.

Given differences in accounting standards and regulatory definitions, however, cross-border comparisons of NPLs must be viewed with great caution. Even within-country time series patterns may not be very informative, since in the 1990s, many countries changed their NPLs classification standards. For example, in Korea, loan classification standards were made more lenient in the mid-1990s, accounting in part for the decline in NPLs from the early- to the mid-1990s.

An implication of our theoretical model is that the stock market value of the domestic banks should 
be declining much more in the crisis cases before the crisis than in the non-crisis cases. This decline should be evidenced by a significant decline in the ratio of the value of domestic bank equities to the stock market value of the entire domestic sector. This comparison allows us to compensate for overall stock market fluctuations and trends. Chart 4a compares these ratios for Korea and Taiwan Province of China. In Korea, the ratio sharply declined between 1992 and 1996, while in Taiwan Province of China, the ratio increased. Chart $4 \mathrm{~b}$ compares these ratios for Malaysia and Thailand. In Thailand, the ratio sharply declined between 1992 and 1996, while in Malaysia, the ratio increased. Thus, the comparison of the ratios indicate that the values of domestic banks were deteriorating in Korea and Thailand, while in Taiwan Province of China and Malaysia, the values of domestic banks were improving. As with cross-border comparisons of NPLs, the cross-border comparisons of bank equity values should also be viewed with caution. Capital markets in many of these economies were still developing, while in Singapore, they were much more mature, making comparisons across economies somewhat dubious. In addition, standards of loan classification, provisioning, and accounting standards varied widely, and it is not clear that market valuations of bank stocks took adequate account of these differences.

\subsubsection{Increases in Money Supply Growth Rates, Post-Crisis}

Currency crisis in our model's equilibrium arise because the sudden increase in the public sector budget deficit is monetized in the wake of a financial crisis. This should result in sharp growth in money supply, post-crisis. Charts 5a and 5b depict the ratio of narrow money to GDP. In Korea, there was sharp growth in the narrow money to GDP ratio in 1998. In Thailand, the growth in narrow money to GDP was more muted, owing to the sterilization of government liquidity support to the banks. In Taiwan Province of China, Malaysia, and Singapore, the narrow money to GDP ratio declined in 1998. (The results are similar if we use the ratio of broad money to GDP).

\subsubsection{The Decline in Loan Collateral Values and Crisis}

Some models, but not our model, emphasize the role of credit constraints based on the value of 
collateral, following Kiyotaki and Moore [1997], for precipitating a crisis under aggregate shocks. These models typically have multiple equilibria, and the decline in loan collateral values, especially real estate values, plays a key role in shifting the economy from a "good" equilibrium to a "bad" equilibrium in which the crisis is self-fulfilling. Charts $6 \mathrm{a}$ and $6 \mathrm{~b}$ plots the trend in real estate values. Only in Thailand have real estate prices started to decline before the crisis. In Korea and in Malaysia, real estate values were constant or rising before the crisis; the real estate values in these two countries

fell only after the crisis. ${ }^{8}$ The decline in real estate prices after the crisis is consistent with any number of models of financial crises.

\section{Conclusions}

The case study comparisons support the hypotheses and implied dynamics of the model of intermediation of foreign capital inflows by the domestic banking system under imperfect information rather well. The pattern of prudential regulation, deposit insurance, foreign currency debt guarantees and corporate reliance on bank credit in Korea and Thailand, two countries that suffered crisis most severely, match the assumptions of the theory well. These institutional features of the economies of Taiwan Province of China and Singapore do not match the maintained hypotheses of the banking model and did not suffer either crisis or display many of the implied dynamics of the model. We also find significant differences in the time series for the ratios of non-performing loans in bank portfolios and the relative stock market value of the banking sector between Korea and Thailand on the one side and Taiwan Province of China and Singapore on the other that are consistent with the theory.

The dynamic relationship between foreign capital inflows and bank lending from the model corresponds roughly to the differences across the crisis and non-crisis economies. The comparisons of the rate of return to assets for the cases studied does not clearly fit the model. However, the production side of the model economy is very simple and does not allow endogenous or exogenous changes in 
the technologies available to investors over time. It also does not pin down how the average rate of return to capital changes with choices of investment projects; this is ambiguous in absence of specific parameterization.

The empirical picture for Malaysia falls between that for Taiwan Province of China and Singapore and that for Korea and Thailand. The relationship between foreign capital inflows and bank lending fits Malaysia except under the imposition of capital controls; this supports the model's implications. The ratio of non-performing loans rises, perhaps as the result of directed lending, while the value of bank shares rises in proportion to the market in the case of Malaysia. With respect to the institutional hypotheses, Malaysia is also an intermediate case. We might argue that this is consistent with our hypotheses, although it may also support the alternative that Malaysia suffered a loss of investor confidence by association leading to a liquidity crisis. 


\section{References}

Aghion, Philippe, Philippe Bacchetta and Abhijit Banerjee [1999a], "Capital Markets and the Instability of Open Economies,” Centre for Economic Policy Research Discussion Paper No.2083, March.

Aghion, Philippe, Philippe Bacchetta and Abhijit Banerjee [1999b], "Financial Liberalization and Volatility in Emerging Market Economies," in P.R. Agenor, M. Miller, D. Vines and A. Weber, eds., The Asian Financial Crisis: Causes, Contagion and Consequences, Cambridge, UK: Cambridge University Press, pp. 167-190.

Aghion, Philippe, Philippe Bacchetta and Abhijit Banerjee [2000], "Currency Crises and Monetary Policy in an Economy with Credit-Constraints," Centre for Economic Policy Research Discussion Paper No.2529, August.

Barth, James, R., Gerard Caprio, and Ross Levine [2000], "Banking Systems Around the Globe," World Bank Development Research Group Working Paper No. 2325, April.

Bernanke, Benjamin and Mark Gertler [1990], "Financial Fragility and Economic Performance,”Quarterly Journal of Economics, 105, February, pp. 87-114.

Bernanke, Benjamin and Mark Gertler [1989], "Agency Costs, Net Worth and Business Fluctuations," American Economic Review, 79, March, pp. 14-31.

Bernanke, Benjamin, Mark Gertler and Simon Gilchrist [1999], "The Financial Accelerator in a Quantitative Business Cycle Framework," in John Taylor and Micheal Woodford, eds., Handbook of Macroeconomics, Vol. 1c, pp. 1341-1393.

Burnside, Craig, Martin Eichenbaum and Sergio Rebelo [1999], "Hedging and Financial Fragility in Fixed Exchange Rate Regimes, ” National Bureau of Economic Research Working Paper No. 7143, May.

Caballero, Ricardo and Arvind Krishnamurthy [1998], "Emerging Markets Crises: An Assets Markets Perspective,” MIT Working Paper.

Calvo, Guillermo [1998b], "Varieties of Capital-Market Crises," in Calvo, Guillermo and Mervyn King (eds.), The Debt Burden and its Consequences for Monetary Policy, London: Macmillan.

Calvo, Guillermo [1998a], "Balance of Payments Crises in Emerging Markets: Large Capital Inflows and Sovereign Governments," NBER Conference on Currency Crises, Cambridge, MA, Febuary.

Chang, Roberto and Andres Velasco [1999], "Illiquidity and Crises in Emerging Markets: Theory and Policy", NewYorkUniversity Working Paper.

Chen, Tsaubin [2000], "The Taiwanese Financial System at the Time of the Asian Crisis," mimeographed, University of Southern California.

Chinn, Menzie and Kenneth Kletzer [2000], "International Capital Inflows, Domestic Financial Intermediation and Financial Crises under Imperfect Information,” in Reuven Glick, Ramon Moreno 
and Mark Spiegel, eds., Emerging Market Crises, New York: Cambridge University Press, pp. 196-237.

Chu, Yun-Han [1999], "Surviving the East Asian Financial Storm: The Political Foundation of Taiwan's Economic Resilience," in Pempel, T.J., ed., The Politics of the Asian Economic Crisis, Ithaca: Cornell University Press.

Collins, Susan and Won-Am Park [1989], "External Debt and Macroeconomic Performance in South Korea," in Collins, Susan and Jeffrey Sachs, eds., Developing Country Debt and Economic Performance, Chicago: University of Chicago Press.

Corsetti, Giancarlo, Paolo Pesenti and Nouriel Roubini [1998a], "Paper Tigers? A preliminary assessment of the Asian crisis," Working Paper no. 6783. National Bureau of Economic Research, Cambridge, MA.

Corsetti, Giancarlo, Paolo Pesenti and Nouriel Roubini [1998b], "What caused the Asian currency and financial crisis? Part I: a macroeconomic overview," Working Paper no.6833. National Bureau of Economic Research, Cambridge, MA.

Corsetti, Giancarlo, Paolo Pesenti and Nouriel Roubini [1998c], "What caused the Asian currency and financial crisis? Part II: theory and policy responses," Working Paper no. 6834 National Bureau of Economic Research, Cambridge, MA.

Christiano, Lawrence, Chris Gust and Jorge Roldos [2000], "Monetary Policy in an International Financial Crisis," paper for First Annual Research Conference, International Monetary Fund, November.

Dekle, Robert, and Angel Ubide [1998], "Korea: Financial Sector Development and Reform,” mimeographed, International Monetary Fund.

Demiguc-Kunt, Asli, and Enrica Detragiache [2000], "Does Deposit Insurance Increase Banking System Stability? An Empirical Investigation,” World Bank Development Research Group, Paper for Deposit Insurance Conference, June.

Diamond, Douglas [1984], "Financial Intermediation and Delegated Monitoring," Review of Economic Studies, 51, pp. 393-414.

Diamond, Douglas and Phillip Dybvig [1983], "Bank Runs, Deposit Insurance and Liquidity," Journal of Political Economy, 91, June, pp. 401-419.

Diaz-Alejandro, Carlos [1985], "Good-bye Financial Repression, Hello Financial Crash,” Journal of Development Economics, 19, pp. 1-24.

Dooley, Michael P. [2000], A model of crises in emerging markets,” Economic Journal, 110, January, pp. 256-272.

Edison, Hali, P. Luangaram and Marcus Miller [2000], “Asset Bubbles, 'Leverage and Lifeboats': Elements of the East Asian Crisis,” Economic Journal, 110, pp. 309-334. 
Eichengreen, Barry and Andrew Rose [1998], "Staying afloat when the wind shifts: External factors and emerging-market banking crises," Working Paper no. 6370. National Bureau of Economic Research, Cambridge, MA.

Flood, Robert and Peter Garber [1984], "Collapsing Exchange Rate Regimes: Some Linear Examples,” Journal of International Economics, 17, August, pp. 1-13.

Frankel, Jeffrey and Andrew Rose [1996], "Currency crashes in emerging markets: An empirical treatment,” Journal of International Economics, 41, pp. 351-368.

Freixas, Xavier and Jean-Charles Rochet [1997], Microeconomics of Banking, Cambridge, MA: MIT Press.

Furman, Jason and Joseph Stiglitz [1998], “Economic Crises: Evidence and Insights from East Asia,” Brookings Papers on Economic Activity, 2, pp. 1-115.

Goldfajn, Ilan and Rodrigo Valdes [1997], "Capital Flows and the Twin Crises: The Role of Liquidity," International Monetary Fund, Working Paper WP/97/87.

Haggard, Steven [2000], The Political Economy of the Asian Financial Crisis, Washington: Institute for International Economics.

Holmstrom, Bengt and Jean Tirole [1997], "Financial Intermediation, Loanable Funds, and the Real Sector," Quarterly Journal of Economics, 112, (August), pp. 663-91.

International Monetary Fund [1999a], "Malaysia: Selected Economic Issues,” mimeographed, International Monetary Fund.

International Monetary Fund [1999b], "Singapore: Selected Economic Issues," mimeographed, International Monetary Fund.

International Monetary Fund [2000a], “Thailand: Selected Economic Issues,” mimeographed, International Monetary Fund.

International Monetary Fund [2000b], “Singapore: Selected Economic Issues,” mimeographed, International Monetary Fund.

Kaminsky, Graciela and Carmen Reinhart [1999], "The Twin Crises: The Causes of Banking and Balance-of-Payments Problems,”American Economic Review, 89(3), pp. 473-499.

Kiyotaki, Nobuhiro and John Moore [1997], “Credit Cycles,” Journal of Political Economy, 105, pp. 211-248.

Krugman, Paul [1979], “A Model of Balance-of-Payments Crises,” Journal of Money, Credit and Banking, 11, August, pp. 311-325.

Krugman, Paul [1999], "Balance Sheets, the Transfer Problem and Financial Crises," in Peter Isard, Assaf Razin and Andrew Rose, eds., International Finance and Financial Crises: Essays in Honor of Robert P. Flood, Dordrecht: Kluwer. 
Kumhof, Michael [1998], "Balance of Payments Crises: The Role of Short-Term Debt," manuscript, Stanford University.

Lindgren, Carl-Johan, Thomas Balino, Charles Enoch and Anne-Marie Gulde [2000], Financial Sector Crisis and Restructuring: Lessons from Asia, Washington: International Monetary Fund.

Mankiw, N. Gregory [1986], “The Allocation of Credit and Financial Collapse,” Quarterly Journal of Economics, 101, pp. 455-70.

McKinnon, Ronald and Huw Pill [1999], "Credible liberalizations and international capital flows: The overborrowing syndrome,” in Ito, T., Krueger, A.O. (eds.) Financial Deregulation and Integration in East Asia. Chicago: University of Chicago Press.

Mishkin, Frederic [1996], "Understanding Financial Crises: A Developing Country Perspective," in Bruno, Michael and Boris Pleskovic (eds.), Annual World Bank Conference on Development Economics 1996, Washington, D.C.: The World Bank, pp. 29-62.

Moreno, Ramon [1996], "Intervention, sterilization, and monetary control in Korea and Taiwan," Federal Reserve Bank of San Francisco Economic Review 1996(3), pp. 23-33.

Obstfeld, Maurice [1998], “The Global Capital Market: Benefactor of Menace?” Journal of Economic Perspectives, 12, pp. 9-30.

Park, Yung Chul [1994], "Korea: Development and Structural Change of the Financial System," in Park, Yung Chul and Hugh Patrick, ed., The Financial Development of Japan, Korea, and Taiwan, Oxford: Oxford University Press.

Pomerleano, M. [1998], "The East Asian crisis and corporate finances: the untold micro story," World Bank Policy Research Working Paper \#1990, World Bank: Washington, DC.

Pomerleano, Michael and Xin Zhang [1999], "Corporate Fundamentals and the Behavior of Capital Markets in Asia," in Harwood, Alison, Robert Litan, and Michael Pomerleano, eds., Financial Markets and Development, Washington: Brookings Institution.

Radelet, Stephen and Jeffrey Sachs [1998], “The East Asian Financial Crisis: Diagnosis, Remedies, Prospects," Brookings Papers on Economic Activity, No 1, pp 1-90.

Rossi, Marco [1999], "Financial Fragility and Economic Performance in Developing Countries: Do Capital Controls, Prudential Regulation, and Supervision Matter?”, IMF Working Paper No. 99/66.

Sachs, Jeffrey, Aaron Tornell and Andres Velasco [1996], "Financial crises in emerging markets: The lessons from 1995," Brookings Papers on Economic Activity, pp. 147-215.

Scott, Kenneth, [1999], “Corporate Governance and East Asia: Korea, Indonesia, Malaysia, and Thailand," in Harwood, Alison, Robert Litan, and Michael Pomerleano, eds., Financial Markets and Development, Washington: Brookings Institution.

Shea, Jia-Dong [1994], "Taiwan: Development and Structural Change of the Financial System," in Park, Yung Chul and Hugh Patrick, eds., The Financial Development of Japan, Korea, and Taiwan, Oxford: Oxford University Press. 
Spiegel, Mark M. [1995], "Sterilization of capital inflows through the banking sector: evidence from Asia,” Federal Reserve Bank of San Francisco, manuscript.

Yang, Ya-Hwei [1994], “Taiwan: Development and Structural Change of the Banking System," in Park, Yung Chul and Hugh Patrick, eds., The Financial Development of Japan, Korea, and Taiwan, Oxford: Oxford University Press.

Stiglitz, Joseph and Andrew Weiss[1981], "Credit Rationing in Markets with Imperfect Information,” American Economic Review, 71, pp. 393-410.

Velasco, Andrés [1987], "Financial Crises and Balance of Payments Crises: A Simple Model of the Southern Cone Experience,” Journal of Development Economics, 27, pp. 263-283. 
Table 1. The Assumptions of the Theoretical Model: Do They Fit?

\begin{tabular}{|c|c|c|c|c|c|}
\hline & Korea & $\begin{array}{l}\text { Taiwan Province } \\
\text { of China }\end{array}$ & Thailand & Malaysia & Singapore \\
\hline $\begin{array}{l}\text { Predominance } \\
\text { of Corporate } \\
\text { Borrowing } \\
\text { From } \\
\text { Domestic } \\
\text { Banks }\end{array}$ & $\begin{array}{l}\text { XXX } \\
\text { Corporate } \\
\text { Bank } \\
\text { Borrowing } \\
\text { Ratio: Over } \\
50 \% . \\
87 \% \text { of } \\
\text { Corporate } \\
\text { Bonds Bank- } \\
\text { Guaranteed. }\end{array}$ & $\begin{array}{l}\text { X } \\
\text { Corporate } \\
\text { Bank } \\
\text { Borrowing Ratio: } \\
\text { About } 22 \% \text {. } \\
\text { High Equity } \\
\text { Financing. }\end{array}$ & $\begin{array}{l}\text { XXX } \\
\text { Corporate } \\
\text { Bank } \\
\text { Borrowing } \\
\text { Ratio: } \\
\text { About 75\%. } \\
\text { Of which 20\% } \\
\text { from } \\
\text { Foreign Banks } \\
\text { (in FX). }\end{array}$ & $\begin{array}{l}\text { XX } \\
\text { Corporate } \\
\text { Bank } \\
\text { Borrowing } \\
\text { Ratio: } \\
\text { About 40\%. } \\
\text { Good } \\
\text { Corporate } \\
\text { Bond and } \\
\text { Equity } \\
\text { Markets. }\end{array}$ & $\begin{array}{l}\text { XX } \\
\text { Corporate } \\
\text { Bank } \\
\text { Borrowing } \\
\text { Ratio: } \\
\text { About 40\% } \\
\text { Strong } \\
\text { Corporate } \\
\text { Bond and } \\
\text { Equity } \\
\text { Markets. }\end{array}$ \\
\hline $\begin{array}{l}\text { Government } \\
\text { Explicit and } \\
\text { Implicit } \\
\text { Guarantees of } \\
\text { Domestic and } \\
\text { Foreign Loans } \\
\text { to the } \\
\text { Domestic } \\
\text { Banking } \\
\text { Sector }\end{array}$ & $\begin{array}{l}\text { XXX } \\
\text { Limited } \\
\text { Explicit } \\
\text { Deposit } \\
\text { Insurance } \\
\text { System. } \\
\text { Depositors } \\
\text { Always } \\
\text { Bailed-Out. } \\
\text { Blanket- } \\
\text { Guarantees of } \\
\text { Foreign Loans } \\
\text { (during } \\
\text { Crisis). }\end{array}$ & $\begin{array}{l}\text { XXX } \\
\text { Limited } \\
\text { Explicit } \\
\text { Deposit } \\
\text { Insurance } \\
\text { System. } \\
\text { Depositors Always } \\
\text { Bailed-Out. }\end{array}$ & $\begin{array}{l}\text { XXX } \\
\text { No Explicit } \\
\text { Deposit } \\
\text { Insurance } \\
\text { System. } \\
\\
\text { Depositors } \\
\text { Always } \\
\text { Bailed-Out. } \\
\text { Blanket- } \\
\text { Guarantees of } \\
\text { Deposits in } \\
\text { Banks, } \\
\text { Finance } \\
\text { Companies, } \\
\text { and Foreign } \\
\text { Loans (during } \\
\text { Crisis). }\end{array}$ & $\begin{array}{l}\text { XX } \\
\text { No Explicit } \\
\text { Deposit } \\
\text { Insurance } \\
\text { System } \\
\\
\text { Depositors } \\
\text { Always } \\
\text { Bailed-Out } \\
\text { Blanket- } \\
\text { Guarantees } \\
\text { of Domestic } \\
\text { Resident } \\
\text { Deposits in } \\
\text { Banks } \\
\text { (during } \\
\text { Crisis). } \\
\text { Foreigners } \\
\text { Faced Losses } \\
\text { on Ringgit } \\
\text { Deposits }\end{array}$ & $\begin{array}{l}\text { XX } \\
\text { No Explicit } \\
\text { Deposit } \\
\text { Insurance } \\
\text { System } \\
\\
\text { Implicit } \\
\text { Guarantees to } \\
\text { Depositors in } \\
\text { Domestic } \\
\text { Banks }\end{array}$ \\
\hline
\end{tabular}


Table 1 (continued)

\begin{tabular}{|c|c|c|c|c|c|}
\hline & Korea & $\begin{array}{l}\text { Taiwan Province } \\
\text { of China }\end{array}$ & Thailand & Malaysia & Singapore \\
\hline $\begin{array}{l}\text { Absence of } \\
\text { Effective } \\
\text { Prudential } \\
\text { Regulation of } \\
\text { and } \\
\text { Supervisory } \\
\text { Forbearance of } \\
\text { the Domestic } \\
\text { Banking } \\
\text { Sector }\end{array}$ & $\begin{array}{l}\text { XXX } \\
\text { Supervision } \\
\text { Fragmented } \\
\text { Between MOF } \\
\text { and BOK. } \\
\text { Prudential } \\
\text { Regulations } \\
\text { Relaxed in } \\
\text { Mid-1990s. } \\
\text { Limits on } \\
\text { Loan } \\
\text { Exposure to } \\
\text { Specific } \\
\text { Corporate } \\
\text { Groups } \\
\text { Disregarded }\end{array}$ & $\begin{array}{l}\text { X } \\
\text { Supervision } \\
\text { Consolidated at } \\
\text { CBC. } \\
\text { CBC Applied } \\
\text { Prudential } \\
\text { Standards Stricter } \\
\text { Than Law. }\end{array}$ & $\begin{array}{l}\text { XXX } \\
\text { Supervision } \\
\text { Fragmented } \\
\text { Between MOF } \\
\text { and BOT. } \\
\text { Loan } \\
\text { Classification } \\
\text { Rules Too } \\
\text { Lenient or } \\
\text { Ignored. } \\
\text { No Limits on } \\
\text { Loan } \\
\text { Exposure to } \\
\text { Specific } \\
\text { Sectors (eg. } \\
\text { Real Estate). }\end{array}$ & $\begin{array}{l}\text { XX } \\
\text { Supervision } \\
\text { Consolidated } \\
\text { at BNM. } \\
\text { Strict Limits } \\
\text { on Connected } \\
\text { Lending and } \\
\text { Lending to } \\
\text { Corporate } \\
\text { Groups. }\end{array}$ & $\begin{array}{l}\text { X } \\
\text { Supersion } \\
\text { Consolidated } \\
\text { at MAS. } \\
\text { Prudential } \\
\text { regulations } \\
\text { comparable to } \\
\text { those in U.K. } \\
\text { Required } \\
\text { Capital-Asset } \\
\text { Ratios (at } 12 \\
\text { percent) higher } \\
\text { than in other } \\
\text { Asian } \\
\text { countries. }\end{array}$ \\
\hline $\begin{array}{l}\text { Total } \\
\text { Rating }\end{array}$ & $\begin{array}{l}\text { XXXXX } \\
\text { XXXX }\end{array}$ & XXXXX & $\begin{array}{l}\text { XXXXX } \\
\text { XXXX }\end{array}$ & $\begin{array}{l}\text { XXXXX } \\
X\end{array}$ & XXXXX \\
\hline
\end{tabular}


Chart 1A: Korea-- Bank Lending, Capital Inflows, Investment
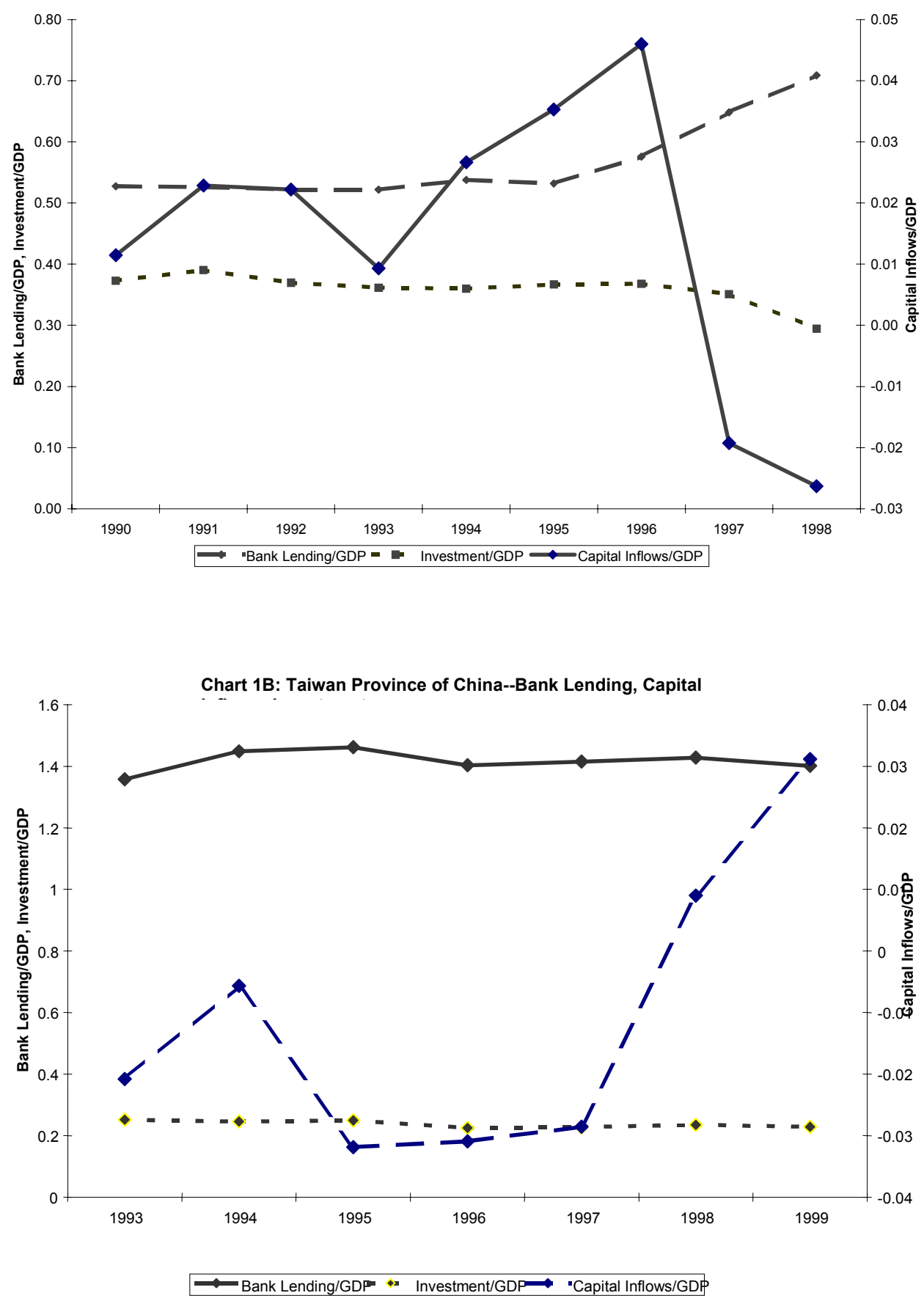
52

Chart 1C: Malaysia--Bank Lending, Capital Inflows, and Investment

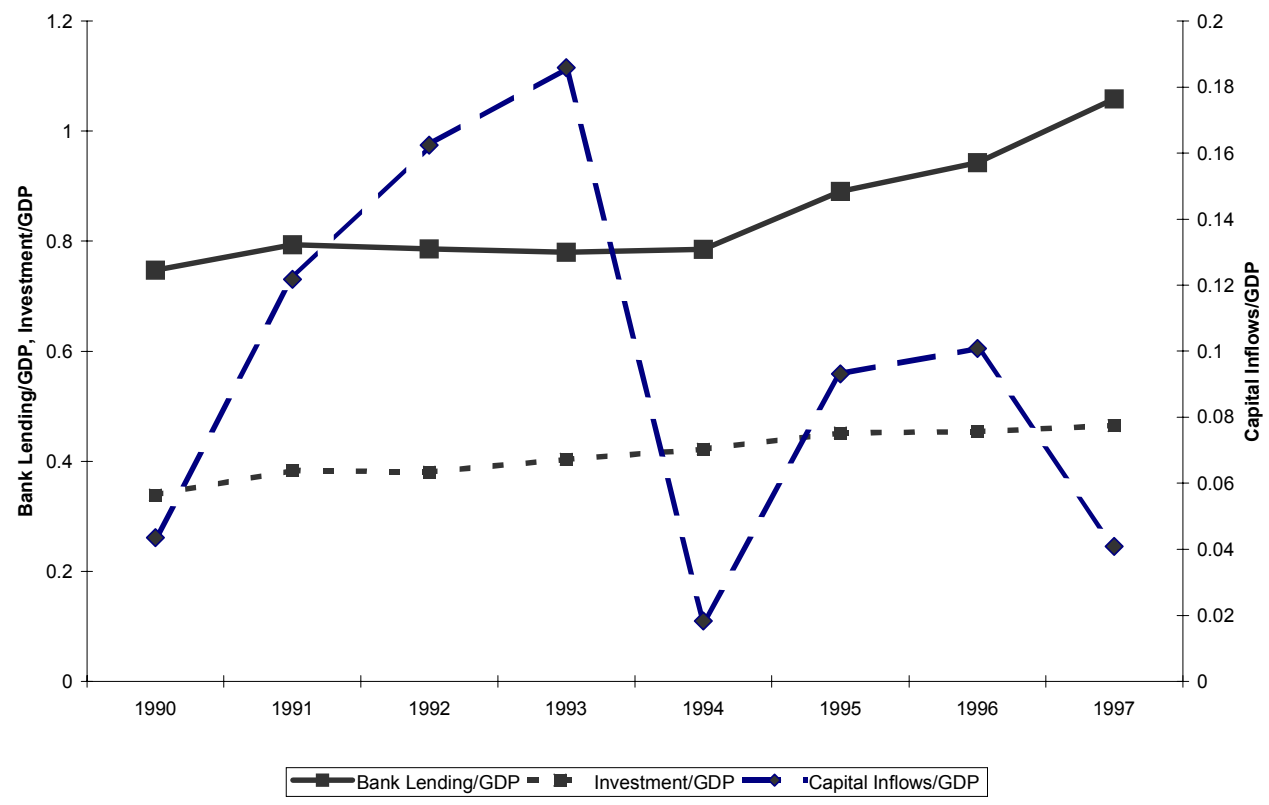

Chart 1D: Thailand--Bank Lending, Capital Inflows, Investment

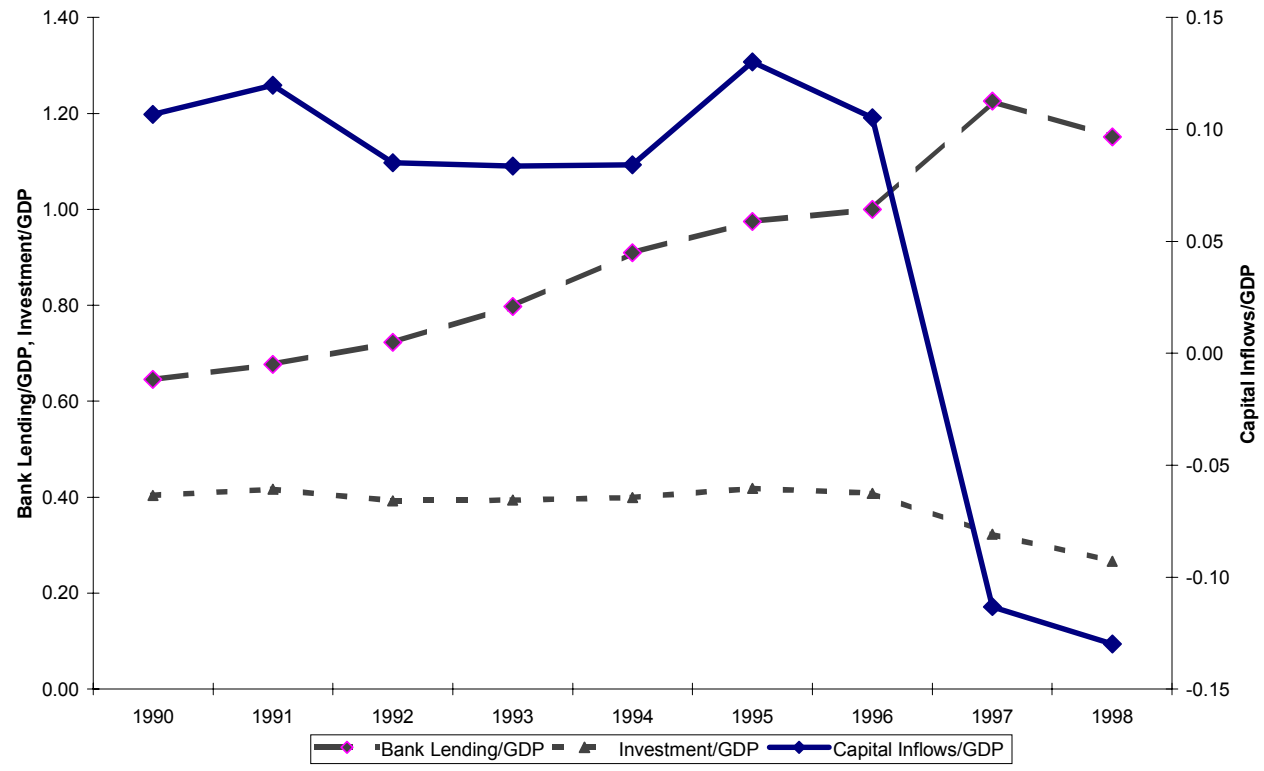


Chart 1E: Singapore--Bank Lending, Capital Inflows, Investment

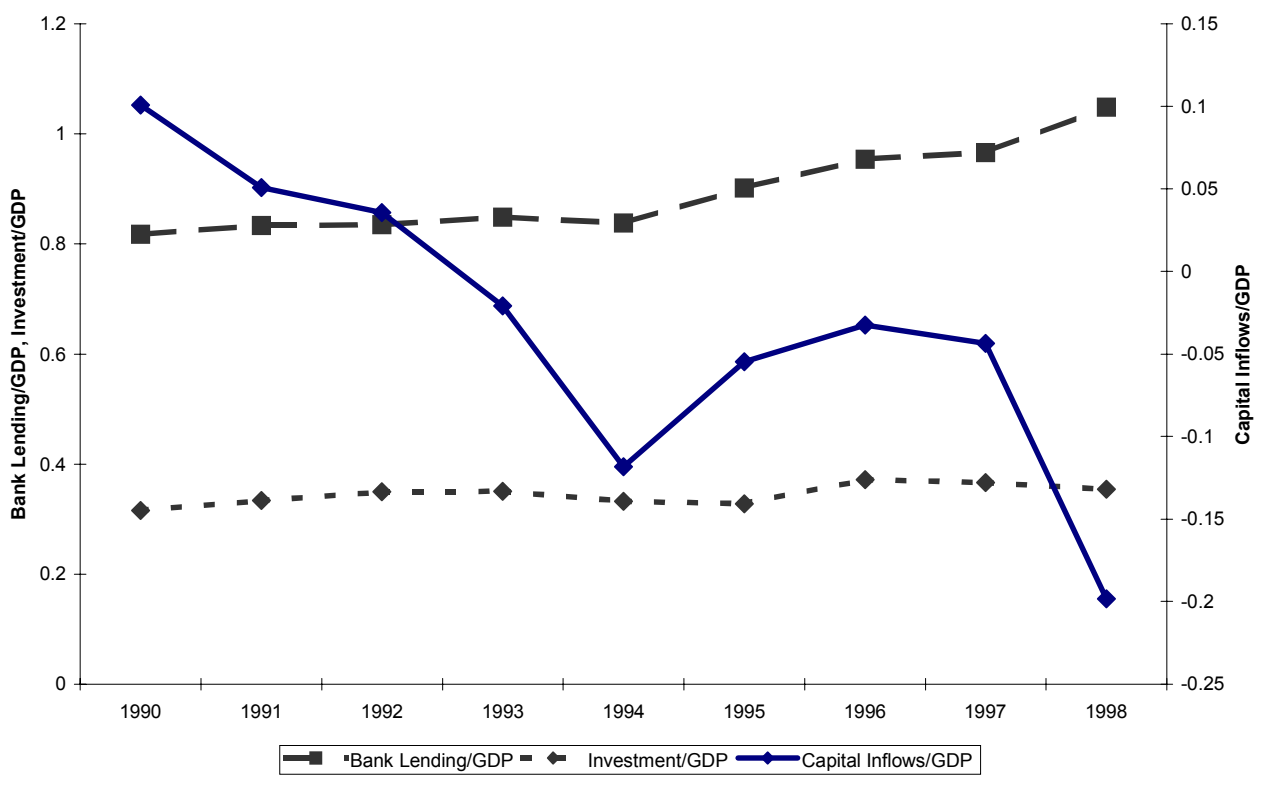




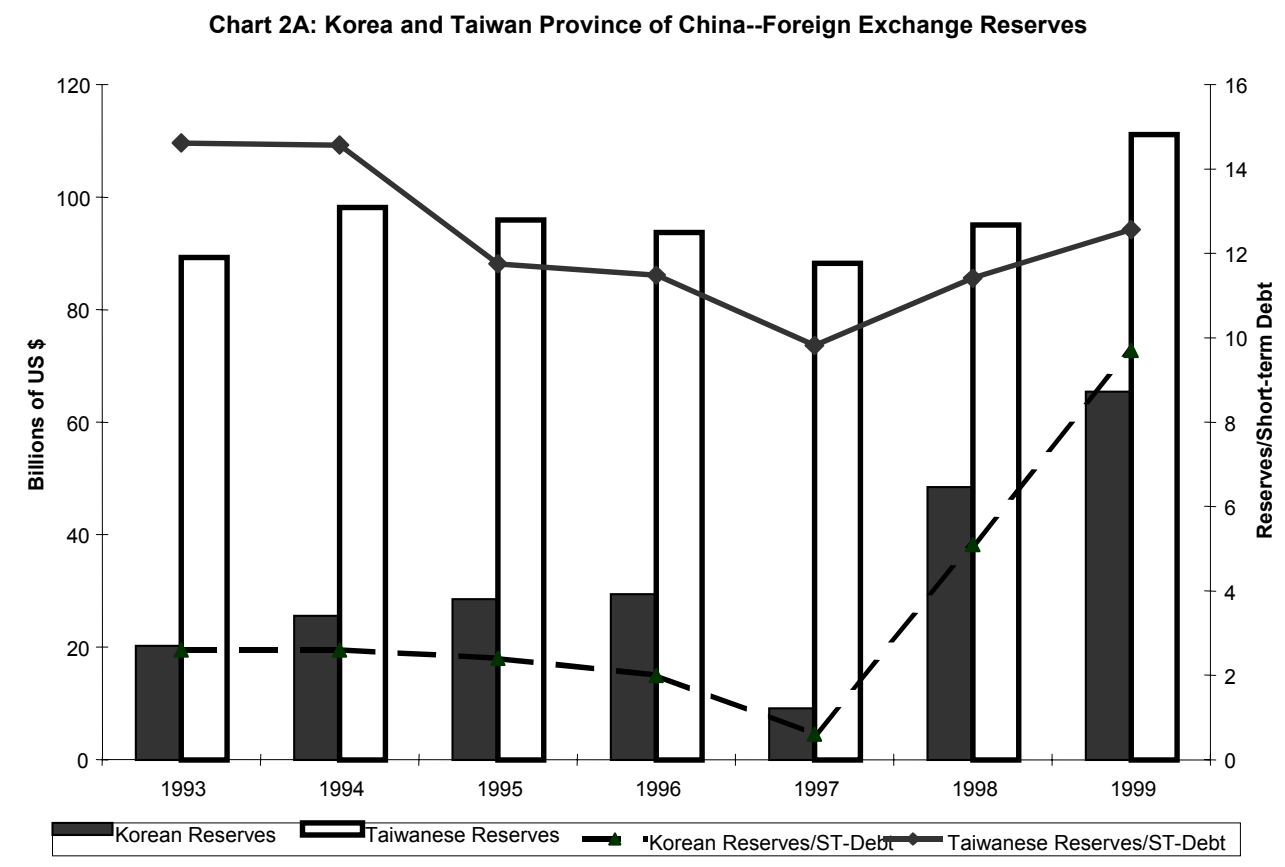

Chart 2B: Malaysia, Thailand, Singapore-- Foreign Exchange Reserves

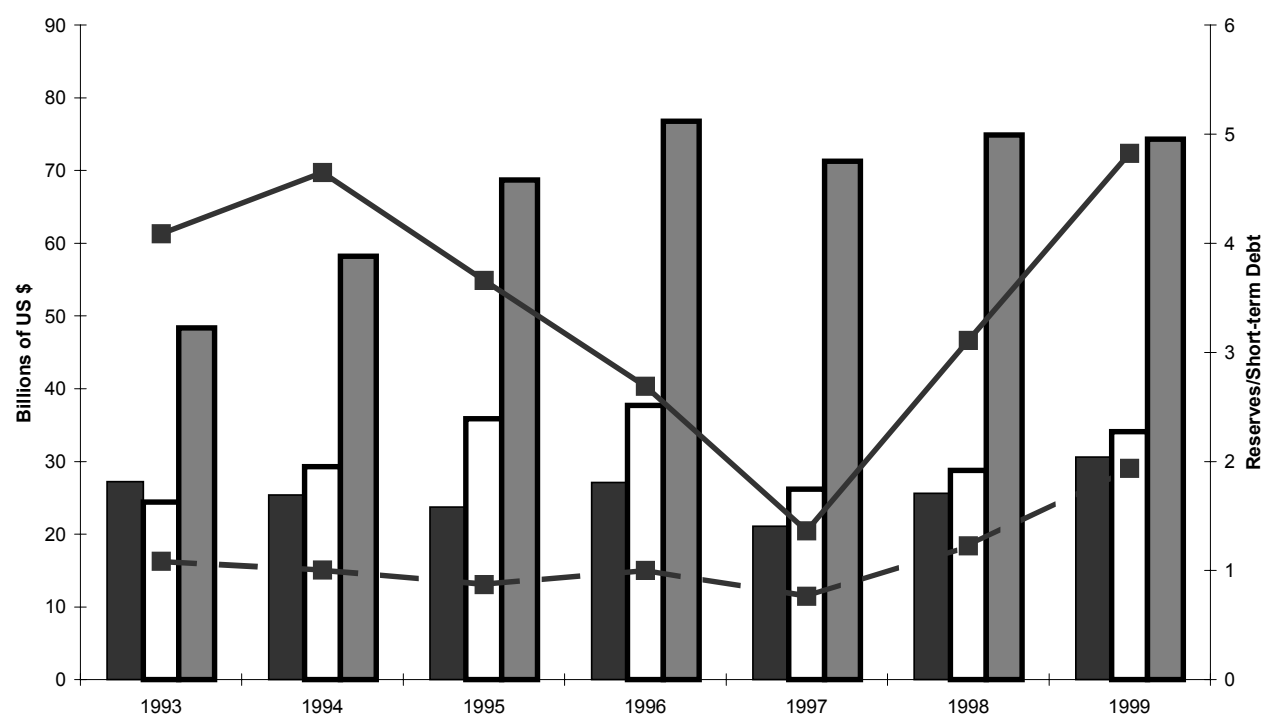

Malaysia Reserves 2 Thai Reserves 2 Singapore Reserves $\rightarrow$ Malay. Res./ST-Debt $\longrightarrow$ 'Thai. Res./ST-Debt 
Chart 3A: Korea and Taiwan Province of China--Nonperforming Loans

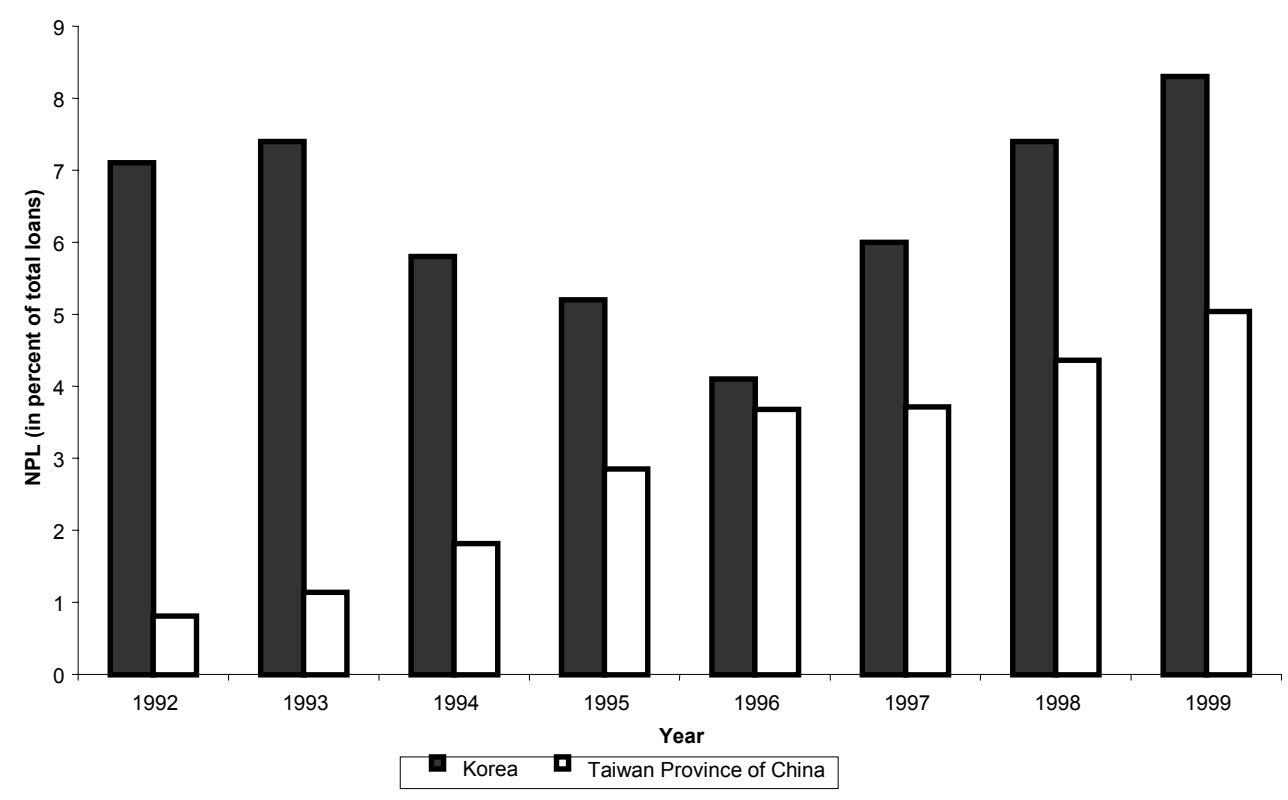

Chart 3B: Malaysia, Thailand, Singapore--Nonperforming Loans

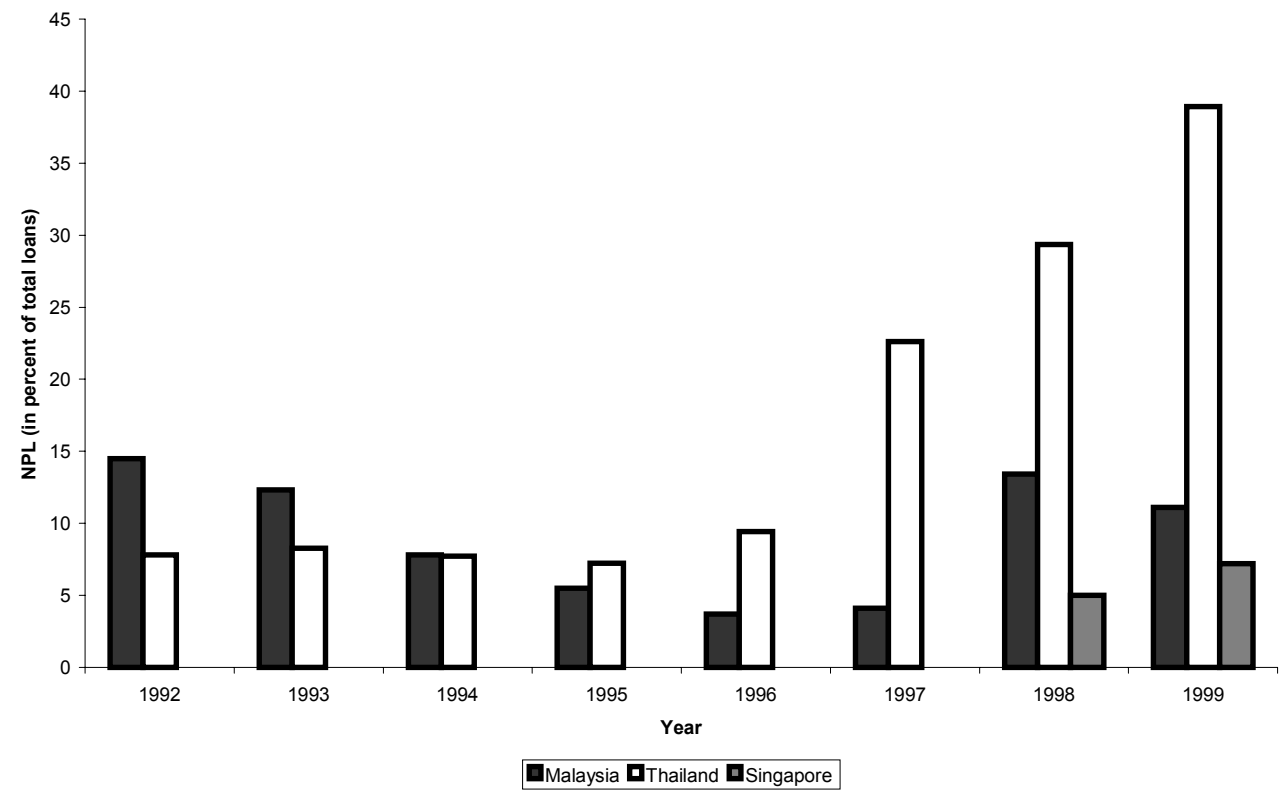


Chart 4A: Korea and Taiwan Province of China--Ratio of Bank Stocks to Total Stock Market Value

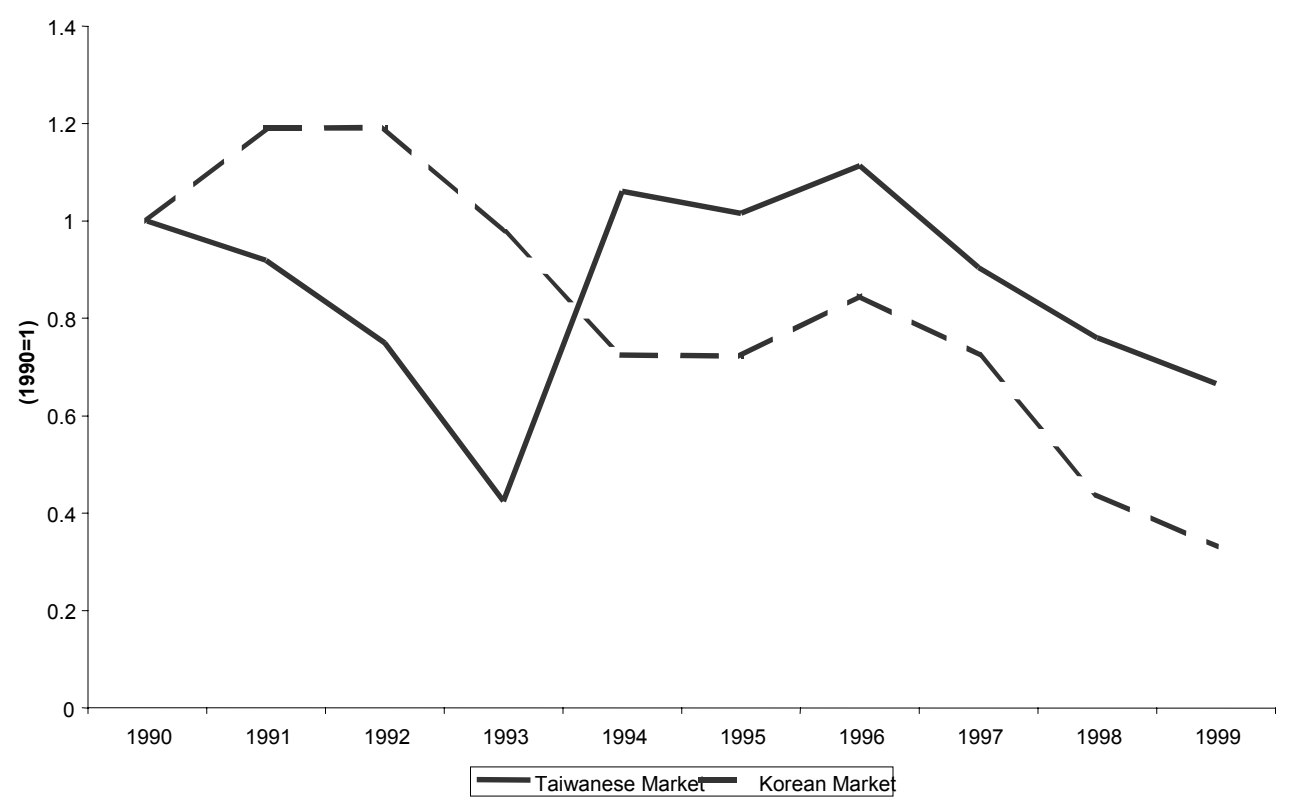

Chart 4b: Malaysia, Thailand, Singapore--Ratio of Bank Stocks to Total Stock Market Value

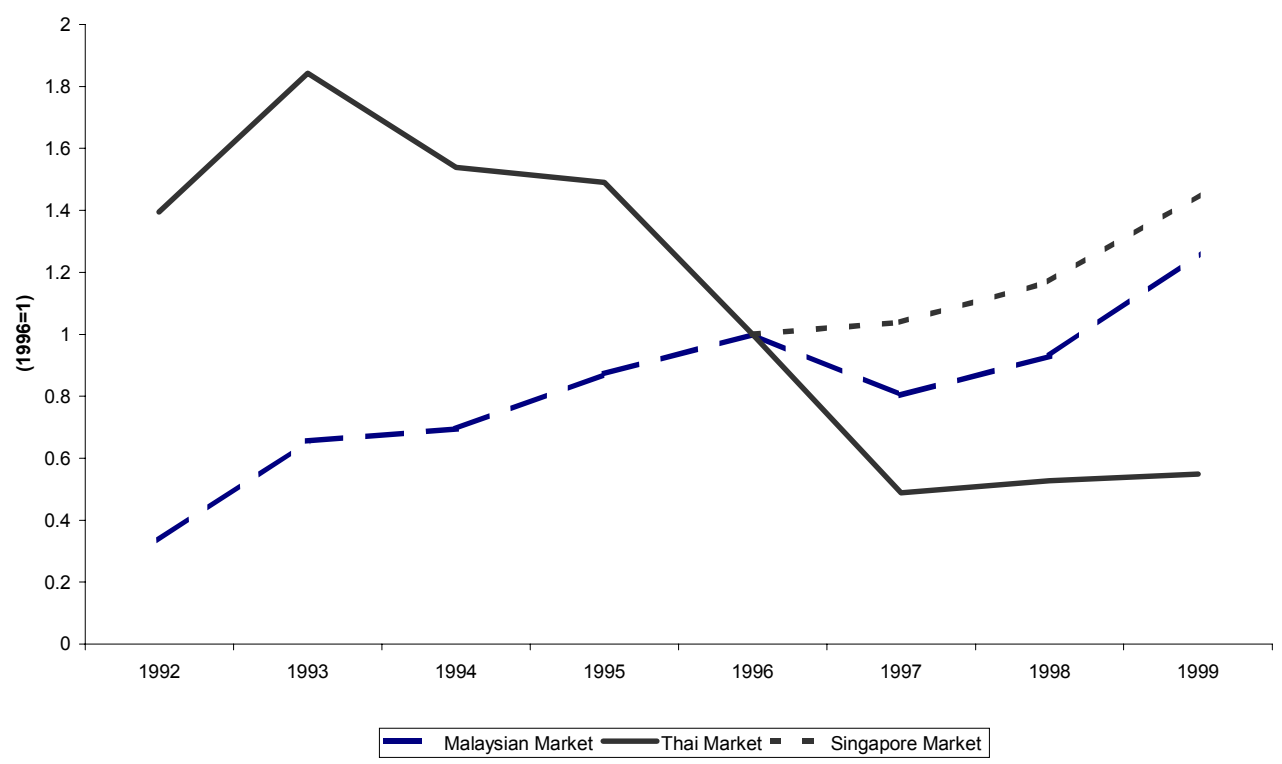


Chart 5A: Korea and Taiwan Province of China--M1/GDP

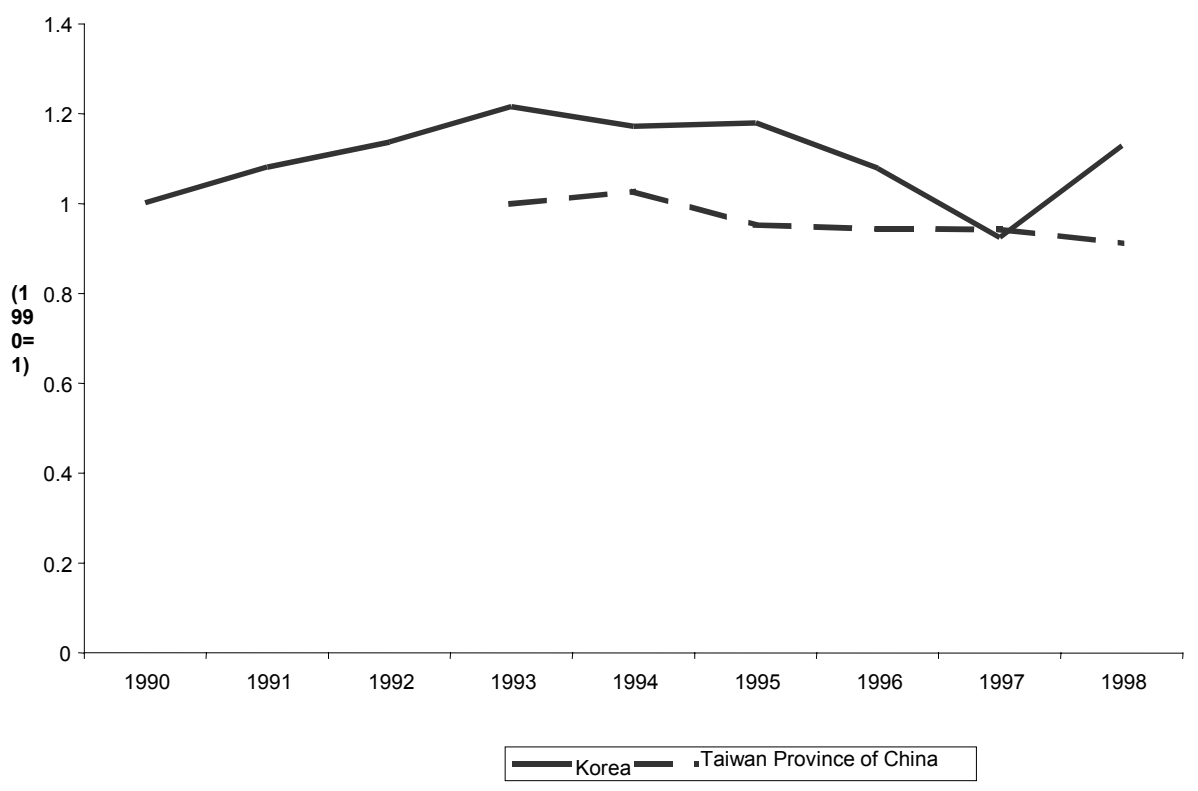

Chart 5B: Malaysia, Thailand, Singapore--M1/GDP

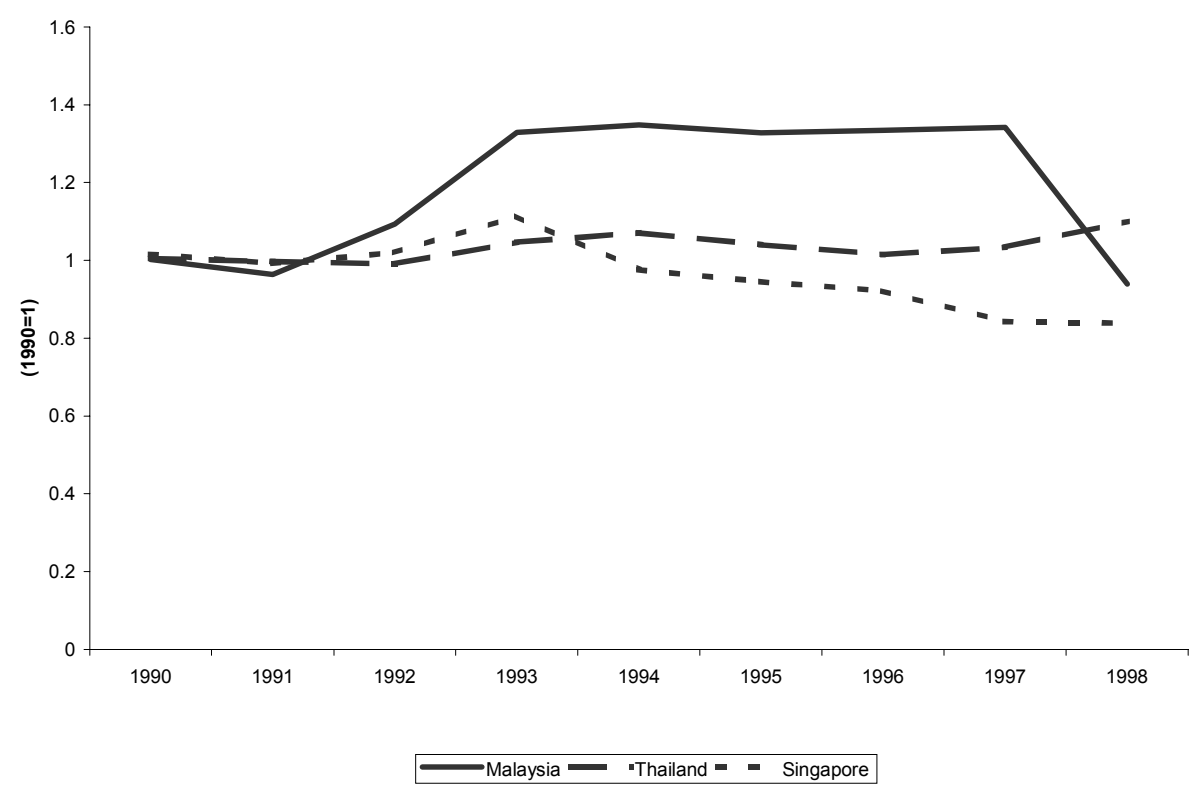


Chart 6A: Korea and Taiwan Province of China --Real Estate Prices

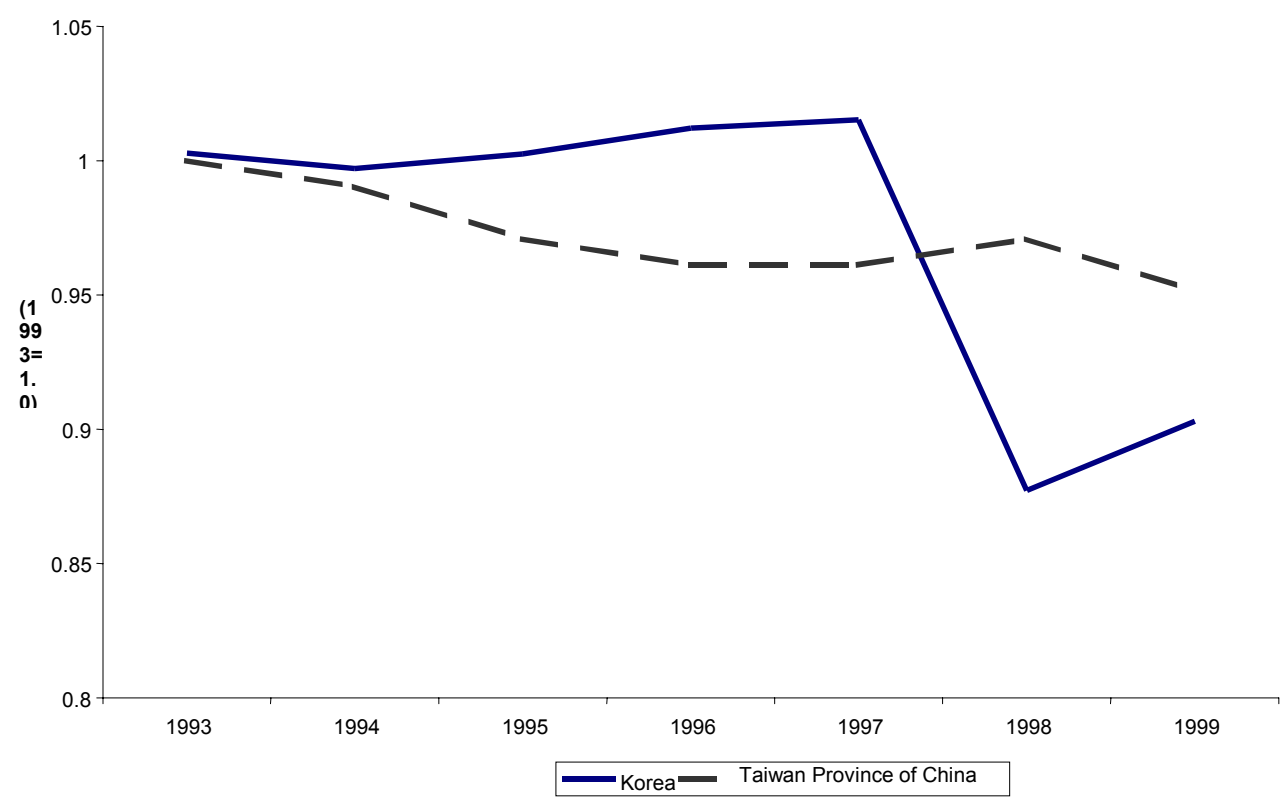

Chart 6B: Malaysia, Thailand, Singapore-- Real Estate Prices

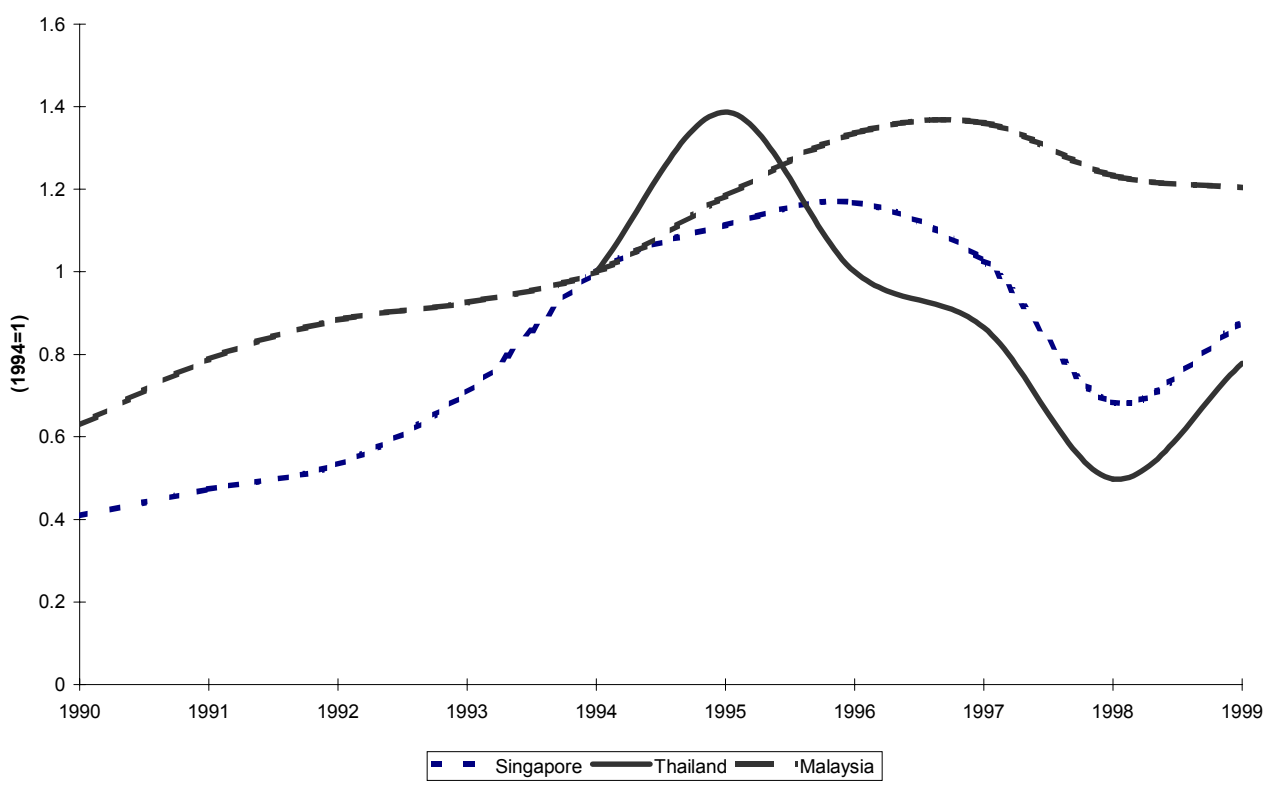


Appendix:

\section{Data Sources For Charts}

\section{Charts 1}

Bank Lending: All countries except for Taiwan Province of China, Claims on Private Sector by Private Money Banks (from IMF International Financial Statistics). For Taiwan Province of China, Claims on Private Sector by Private Money Banks (from Central Bank of China Web Page).

Capital Inflows: All countries except for Taiwan Province of China, Financial Account of Balance of Payments (from IMF International Financial Statistics). For Taiwan Province of China, Financial Account of Balance of Payments (from Central Bank of China Web Page).

Investment: All countries except for Taiwan Province of China, Investment in the National Accounts (from IMF International Financial Statistics). For Taiwan Province of China, Investment in the National Accounts (from Central Bank of China Web Page).

GDP: All countries except for Taiwan Province of China, GDP in the National Accounts (from IMF International Financial Statistics). For Taiwan Province of China, GDP in the National Accounts (from Central Bank of China Web Page).

\section{Charts 2}

Reserves: All countries except for Taiwan Province of China, Reserves (from IMF International Financial Statistics). For Taiwan Province of China, Reserves (from Central Bank of China Web Page).

Short-term Debt: All countries and provinces (from country central bank web pages).

\section{Charts 3}

Non-performing Loan Ratios of the Banking Sector: For Korea, NPLs of Deposit Money Banks (from Bank of Korea Web Page). For Taiwan Province of China, NPLs of Deposit Money Banks (from Central Bank of China, personal correspondence). For Thailand, NPLs of Financial Institutions, including Finance Companies (from Bank of Thailand Web Page). For Malaysia, NPLs of Financial Institutions, including Finance Companies (from Bank Negara Malaysia, personal correspondence). For Singapore, NPLs of Financial Institutions (from Monetary Authority of Singapore Web Page).

\section{Charts 4}

Stock Market Values of Domestic Banks and Stock Market Values of Entire Domestic Sector: For all countries and provinces (from Bloomburg Financial Services). 


\section{Charts 5}

Money Supplies: All countries except for Taiwan Province of China, Narrow Money (from IMF International Financial Statistics). For Taiwan Province of China, Narrow Money (from Central Bank of China Web Page).

\section{Charts 6}

Real Estate Values: For Korea (from Social Indicators of Korea). For Taiwan Province of China, (from Government of Taiwan Province of China, private correspondence). For Thailand, Malaysia, and Singapore (from Bloomberg Financial Services). 